\title{
Toplumsal Mekân ve Düşünümsel bir Kent Sosyolojisinin İnşası: Bourdieucülüğün Mekâna Müdahalesini Sorunsallaştırmak
}

\author{
Sinan Tankut Gülhan \\ Gaziantep Üniversitesi
}

\section{Öz}

Bu yazı, Pierre Bourdieu'nün "toplumsal mekân” kavramının yeni kent sosyolojisinin en önemli yayın mecraı ve kurumsal yapısı olan International Journal of Urban and Regional Research üzerinden alanı nasıl tanımladığını, hangi kırılma noktalarına hitap ettiğini, bu kırılma noktaları aracılığıyla nasıl bir bilimsel kopuş müdahalesi, benim deyişimle doksaya yönelik bir "huruç," tertip ettiğini açıklamayı amaçlar. Bunu yaparken IJURR'un son kırk yıldaki arşivini gözden geçirerek Bourdieu'nün kavramlarının kullanımını inceler. Yeni kent sosyolojisi ve Marksist şehirciliğin mekân anlayışı ve yorumu son kırk yılda önemli değişimler geçirdi. Ancak özellikle 2000'li yıllardan itibaren Bourdieu'nün kuramsal etkisi bir dizi araştırmayla kendini göstermeye başladı. Bu etkiyi araştırırken üç farklı durak noktasından geçmemiz gereklidir. $\mathrm{Bu}$ yazıda, öncelikle yeni kent sosyolojisinin ve eleştirel kentsel kuramların Chicago Okulu'na bir tepki olarak nasıl ortaya çıktığını incelenmiştir. İkinci durak noktasında, Castells'in kurucu etkisi altında kurulan yeni kent sosyolojisinin 1970'lerden 1980'lere dönüşümünü ele aldım. Üçüncü durak ise yeni kent sosyolojisinin geri çekilme noktasında Bourdieu'nün yapıtının öncelikle Anglofon sosyolojide, sonra da kent sosyolojisinde nasıl temellük edildiğiyle ilgilidir. Burada, 1980'lerden itibaren IJURR'un sayfalarında Bourdieucü sosyolojik programın nasıl ele alındığını çalıştım. $\mathrm{Bu}$ önemli durakta, öte yandan Bourdieu'nün metinlerinin toplumsal mekânı nasıl ele aldığı da incelenmiştir. Son kısımda, Bourdieu'nün yapıtının yeniden inşa edilmekte olan bir kent sosyolojisi için sunduğu programın eleştirisi ve kazanımları meta-kuramsal bir çerçeve içinde değerlendirilmiştir.

Anahtar Kelimeler: Pierre Bourdieu, yeni kent sosyolojisi, kentsel kuram, toplumsal mekân 


\title{
Social Space and the Genesis of a Reflexive Sociology: Bourdieu's Interventions in the Study of Space
}

\author{
Sinan Tankut Gülhan \\ Gaziantep University
}

\begin{abstract}
This paper focuses on the concept of "social space," a key concept developed by Pierre Bourdieu for advancing his sociological research program. In investigating the possible novel venues of sociological inquiry opened up by the intervention provided by Bourdieu's use of social space, this paper ventures into the archives of International Journal of Urban and Regional Research to understand how Bourdieu's work was reflected upon within the field of urban research in the last four decades. New urban sociology and Marxist urbanism's understanding and interpretation of space has changed significantly throughout the years. Yet, Bourdieu had a certain theory effect, and this has acted upon a steady stream of research, especially since the 2000s. IJURR had gone through what we can call a series of theoretical ruptures in the three decades. Hence, while investigating the Bourdieu's ouevre three important moments are animated here: first, the inherent rupture of the 1960s as a reaction to the Chicago School and its quantitative inheritors are explicated. Second moment requires a critical engagement with the new-born -or, still-birth- new urban sociology and how Manuel Castells' theoretical approach created a new doxa in the academic field. 1970s and 1980s was a crucial point of transformation for the urbanists. In the third moment, I investigated how Bourdieu's analysis was appropriated in the symbolic space of the sociological and urban sociological field. Bourdieu's conceptual framework created a plethora of new approaches, however, their analytical relationship with both Bourdieu's sociological program and the hitherto prevalent spatial imagination is frequently questioned. Here, I suggested an objectification of the Bourdieu's theoretical and research work and tried to locate the breaks and continuities.
\end{abstract}

Keywords: Pierre Bourdieu, new urban sociology, urban theory, social space 
Entelektüel alan...bir manyetik alan gibi güç [iktidar] hatlarından oluşur.

(Bourdieu, 1969, s. 89)

\section{Giriş: Bourdieucülüğün Mekâna Müdahalesini Sorunsallaştırmak}

1990'ların artık kanonikleşmiş ve popüler kültür dünyasından düşünce dünyasına sızmış efsanevi komedi dizisi Seinfeld'in bölümlerinden birinde, ağır bir anti-kahraman olan George Costanza, sevgilisiyle arkadaşlarının tanışmasından sonra meşhur ve korkunç yakınmasıyla bağırmaktadır, "the worlds are colliding, the worlds are colliding." Dünyalar çarpışıyor, dünyalar çarpışıyor. Bourdieu'nün kent literatürüne girişi, girişinden de fazlası, Bourdieucülüğün hurucu, öyle bir etki yaratt. Dünyalar çarpışıyor. Bourdieu, Marksizmin ana kanallarından gelmedi. Daha yakından baktığımızda, tam da kılcal damarların kırılma noktasından Bourdieucülüğün doğduğunu, Ecole Normale Superieure öğrencisi, Althusser'in tüllabından, yapısalc1lığın ve bilakis, Levi-Strauss murisinin taşıyıcısı olduğunu görebiliyoruz. Ne var ki, Bourdieu'nün muris karakteri, bana bu saydığım isimlerden ziyade Durkheim'i, mutlaka onun fazlasıyla değişkenler sosyolojisi olarak tanımlayabileceğimiz yanın, Weber'i, büyük ihtimalle Weberciliğin anti-pozitivist pozitivizmini akla getiriyor.

Bu yazıda, Pierre Bourdieu'nün "toplumsal mekân" kavramının yeni kent sosyolojisinin kurucu kurumsal yapisi olan International Journal of Urban and Regional Research üzerinden alanı nasıl tanımladığını, hangi kırılma noktalarına hitap ettiğini, bu kırılma noktaları aracılığıyla nasıl bir bilimsel kopuş müdahalesi, benim deyişimle bir "huruç," tertip ettiğini açıklamayı amaçlyyorum. Bourdieu'nün de ssrarla işaret ettiği gibi sosyal bilimlerin kendi içinde hareketini anlamaya çalışıyorsanız "nesneleştiren özneyi nesneleştirmekten kaçınamazsınız. (Bourdieu, 1988, s. xii)"

Tabii, bazen, eleştirel öznenin bile nesneleşmenin nesnesi olması kaçınılmaz. Bourdieu'nün anaakım sosyal bilimler içinde Marksist sayılması giriş kitaplarının basitliğinin bir ürünü. Öte yandan, Marksist olup olmamasını bir önemi yok. Fakat, bir yandan giriş kitaplarının komplike olanı karmaşıklaştırmasının, öte yandan, ana metinlerin mistifikasyonunun ürünü olarak, Bourdieu'nün mekâna müdahalesinin esas güzergâhı gözden kaçıyor. Bu yazıda, Bourdieu'nün toplumsal mekân kuramının, esasında toplumsal sınffların bir illüzyon, gerçekliğin dışında bir politik ve akademik kurgu olduğu varsayımılla başlayan bir atağın sonucu olduğunu iddia 
edeceğim. Bourdieucü toplumsal mekân, kendisinin de belirttiği gibi, sosyolojiyi sosyal topoloji olarak gören (Bourdieu, 1984), ama sosyolojiyi fiziksel mekâna getiren, yapılı çevreyle iştigâl eden, tarihsel-coğrafi bir analiz sunan bir yaklaşım değil. Bu yazıda değinmeye çalışacağım gibi, Bourdieu'nün Marksizmi, Costanza'nın deniz biyoloğu olması gibi -mimar olması gibi değil- bir ikili hareket barındırıyor içinde. Marksizme dair bir müstehzi tavrı var, onunla mücadelesi süreğen bir mücadele -muhtemelen doğru bir mücadele. Bazen, etkisini silemeyeceğiniz ağırlıkta düşünürlerin ömrü bitse de, düşüncelerinin ömrü durmuyor, kendi içinde kendini yeniden üretmeye devam ediyor. Filhakika, Bourdieu'yü övmek gerekiyor, ama hem övüp hem de kendi geliştirdiği nesneleştiren nesne olarak idrak edebiliriz. Belki de Platon'un bize öğrettiği en gizli sır bu, hocalarınızı nesneleştirdiğinizde, onları övmeye de devam edebilirsiniz; tabii, eğer hocanızı yeniden üretmemişsiniz. Zirâ, her tüllab hocasını yeniden yaratır-bazısı yeniden üretir. Ya da, Richard Swedberg'in T.S. Eliot'tan esinlenerek söylediği gibi, “olmamış şairler taklit eder, olgun şairler çalar" (T.S. Eliot, 1920/1964, s. 125; Swedberg, 2011, s. 68).

Sosyal bilimlerin Bourdieu'ye medyun olması gerektiğini düşünüyorum. Burada huruca karşı bir huruçtan bahsedilmemektedir, Homo Academicus'ta (1988) Bourdieu'nün işaret ettiği gibi polemik için polemiğin alanda yer belirlemesine dair bir metin değil bu. Bütün diğer kavram kümelerini, habitus'u, çoklu mütekabiliyet analizini, allodoxia'yı, konumların hareketliliklerini, meta-sosyolojiyi ya da sosyolojinin sosyolojisini bir kenara bıraksak bile -ki, bırakmama taraftarıyım- salt toplumsal sinifların alanların ta kendisi olduğu iddiası bile sınıf çalışmaları açısından son derece zihin açıcı, ilerideki araştırmalar açısından belirleyici nüveleri içinde barındırmakta.

Öte yandan, Bourdieu'nün mekânı, metaforik bir mekân, toplumsal olanın yapısal konstrüktivizminde -ya da, konstrüktivist yapısalcılığında(1989) konstrükt edilen, inşa edilen bir temsil mekânı. Her şeyden önce, sosyologlar için bir mekân burası, farkların, değişkenlerin, chi-kare analizlerinin, çoklu mütekabiliyet analizlerinin yaşaması için kurulan bir yer. Kentsel düşüncenin doğuşu ve gelişmesinde böylesi çok yer oldu, beşerî ekolojiden, habitat'a, mimarinin ve plancının mekânından, sınıfsal ayrımların mekânına, üçüncü dünyadan, küresel kentlere ve hattâ üçüncü mekâna değin bu tropelar, Bourdieu'ye göre phonemeler, bu söylem birimleri, kendini yeniden üretmeyi başardı.

Kent hakkında düşünce, Batı felsefesi kadar eski; Platon'un mağara alegorisini de, iyi bir site devleti kurmak hakkında Devlet'teki görüşlerini de 
bunun başlangıcı saymak pekâlâ mümkün. Buna, Aristoteles'in ideal site devleti hakkındaki spekülasyonlarını, St. Augustine'in Aristoteles'ten yola çıkarak uhrevi bir şehir tahayyülünü, bizim coğrafyamızda, farklı nevî İbnHaldun güzellemelerini -1970'lerde soldan, günümüz muhafazakârlığına kadar uzanan- görmek olası. Bir kavram ebedileştiriliyorsa, onun sosyal bilimsel açıdan yok edildiğini, gündelik iktidar söylemine massedildiğini iddia edebiliriz. Kent düşüncesinin bir toplum tahayyülü olduğunu söylemek yerinde olabilir; fakat bu, toplumları çalışmanın ezel-ebed denklemine kentselliği dahil ederek aslında mekânsal olanı ilga etmek anlamına da gelebilir. Somut ve soyut arasındaki ilişkisel gerginlik hattının en ciddi sorunu burada yatıyor; mekânı tekdüzeleştirmekte.

Bu yazıda, Pierre Bourdieu'nün kent sorununa "toplumsal mekân" kavramıla nasıl müdahil olduğunu üç duraktan geçerek irdelemeye çalışacağım. İlk durakta Chicago Okulu'nun kuruluşu ve kente dair hegemonik paradigmayı inşa etmesi yer alıyor. Bir hayli tafsilatlı sayılacak bu durağı hızlıca geçmekte fayda var; fakat iki noktayı görüş açımıza taşıması açısından önemli, birincisi Aristoteles'in site'sini Chicago Okulu'nun kent'ine çeviren benzeşlik, ikincisiyse, hegemonik söylemin kendi reddiyesini nasıl hazırladığı.

İlk durak Chicago Okulu'yla başlıyor fakat onun reddiyesini de içeriyor. $\mathrm{Bu}$ istikamete ancak büyük bir kopuştan geçerek varabiliriz, sosyoloji ve genel hatlarıyla mekânla iştigâl eden sosyal bilimlerin, ekonomi-politikten coğrafyaya, siyaset biliminden kamu yönetimine, neoklasik iktisattan mimarlığa kadar uzanan geniş bir alanlar silsilesinin mekânı kavrayışındaki büyük kırılmadan bahsedeceğiz. Manuel Castells' in devrimi bu, neredeyse tek başına inşa ettiği bir paradigma, bir noktadan sonra tek başına bıraktığı bir devrim de.

İkinci durak, sosyal bilimlerin mekânın bilimsel ele alınışına dair alanı nasıl kurduğuyla doğrudan ilintili. Burada en belirgin kurum, akademik dergicilik ve o dergiciliğin nasıl şekillendiği. Kentsel mekâna dair tahayyülün ve International Journal of Urban and Regional Research [bundan sonra, kısaca IJURR] isimli akademik bir dergi etrafında inşa edilen paradigmanın, ya da alanın, bilimsel parametrelerin, nesneleştirmenin ve daha da önemlisi söylemin nasıl üretildiği yönünde çok parlak çalışmalar var (Crysler, 2003; Milicevic, 2001; Topalov, 1989; Zukin, 1980). Bu durak, Manuel Castells'i tarihsel açıdan konumlandırmayı, onun kuramından neşet eden kentsel ideoloji eleştirisinin nereye dönüştüğünü incelemeyi hedefliyor. 
Üçüncü ve nihai durağımızda ise IJURR'da Pierre Bourdieu ve varisi Loic Wacquant'in metinleri yer alıyor. Bu durakta, IJURR'un Sociology Source Ultimate'ta yer alan tam metin veritabanından yararlandım. Temel mesele esasında bir hayli belirgin: Bourdieu'nün 1980'lerde oluşmaya başlayan düşüncesi mekânı da, kendisinin kavramsallaştırdığı adıyla müsemma "toplumsal mekân" olarak içeriyor ve ilgilendiriyor. Oysa 2000'lerin ortalarına kadar, IJURR'da yayınlanan metinlerin sadece çok kısıtlı bir parçası Bourdieu'nün araştırma sorunsalına ve yaklaşımına yönelim gösteriyor. Öyle ki, 1990'lar ve 2000'lerin başlarında, "sosyal sermaye" kavramı, Bourdieu'nün bir çok kavramsal mekanizması ve manivelalarından çok daha fazla iş görüyor. Aynı yıllar, Amartya Sen'le beraber, Dünya Bankası ekseninde küreselleşme tartışmalarının da bir hayli yoğun ağırlık kazandığı yıllar. Ne var ki, Bourdieu'nün kendisi küreselleşme lügatına, neoliberalizmin kontrolsüz bir biçimde toplumsal alanda konumlanışına dair yazdığı çok ağır eleştirilerle yanıt verdi (Bourdieu, 1998).

Bu durakta, Bourdieu'nün 1980'lerin başından itibaren toplumsal mekân kavramını nasıl dokuduğunu ve aynı zamanda IJURR'da yoğunlaşan yeni kent sosyolojisinin ve eleştirel kentsel kuramların Bourdieu'nün ürünlerini, kuramsal pratiğini nasıl fiiliyata döktüğünü inceleyeceğim. Durağın varacağ1 nokta, Wacquant'ın 2018 başında IJURR'da hazırladığ1 Bourdieucü programatiğin ilân edildiği sayı ve bu tür bir mekânsal tahayyülün alanı nasıl tasvir ettiği olacak. Bourdieucü mekânsal tahayyül üzerinden kentsel kuramların kırılma noktalarının ve inşa güzergâhlarının mukayesesini yapmaya çalışacağım. Mike Savage bu yönde bir çabayı Bourdieu'nün "kayıp kent sosyolojisini" bulmak olarak tanımlasa da (2011), Loïc Wacquant (2018, s. 91) ise mekânsallığın en başından beri Bourdieu'nün lügâtının bir parçası olduğunu iddia edecektir.

Bu yazı, bir taraftan Bourdieu'nün bir güç [iktidar] hatları alegorisiyle resmettiği alan kuramını kendi yansımasıyla değerlendirmeye çalışırken, öte taraftan da kent kuramının IJURR üzerinden yapılan bir içerik analizi yoluyla 1970'lerden bu yana dönüşümünü ele almayı amaçlamaktadır. Bu dönüşümü anlayabilmemiz için ise kentin bir nesne olarak sosyoloji alanına nasıl temellük edildiğinden, yani Chicago Okulu'nun kurucu etkisinden başlayacağı. 


\section{Kentsel Bilimin Oluşumu: Chicago Okulu}

Robert Park, şehri bir bilim nesnesi olarak kurmaya kalkıştı̆̆ında anladığı ve tasarladığı sosyolojiyi epeyi sarih bir biçimde ortaya koydu. "Şehir özellikle de insan ilişkilerinin çıkarlar ve para üzerinden tanımlandığı, genellikle rasyonel ve daha az şahsi olduğu büyük şehir- kitlesel davranışın araştırılması için gerçek anlamda bir laboratuvardır." (Park \& Burgess, 2015, s. 59). On dokuzuncu yüzyılın bütün sosyolojik mirasını taşıyan bu tanım bize bir katman meseleyi özetler. Birincisi, sosyoloji, diğer pozitif bilimler gibi bir laboratuvara ihtiyaç duyar ve bu laboratuvar da sosyal gerçekliğin ta kendisidir.

Albion W. Small'un kurduğu Chicago Okulu başlangıcından itibaren Herbert Spencer'ın Darwinizm sosuna bulanmış toplumsallık yorumuna medyun, Marx'ın ekonomi-politik eleştirisine tepkiliydi. Methodenstreit daha kendini göstermeden, Small sosyolojinin programatik yaklaşımını belirtti: "Bazı akademisyenler hâlâ sosyolojinin bir biçimden yoksun ve boşluktan ibaret olduğunu ve bunun da sonsuza kadar böyle sürmesi gerektiği düşüncesindeler. (Small, 1895, s. 6)" Bu nedenle diyerek ekler, bu akademisyenler için sosyoloji sadece yeni kuramcilara ait bir yerdir. Small, teknik argümanlarla mücehhez bir sosyolojinin otantik bir sosyal felsefe talebi olduğunu iddia edecektir. Kurduğu Chicago Sosyoloji Bölümü de, bizim daha sonraları kulak aşinalığı taşıyacağımız bir iddiayla yola çıkar, Chicago bir sosyoloji laboratuvarıdır.

Park'ın, Small'dan mülhem ikinci saptaması, şu üç kavram kümesinde yer alır: rasyonellik, gayri-şahsilik ve para-çıkar ilişkisi. Chicago Okulu, bohemliği, suçu, sapkın davranışları çalışmasıyla zamanı için bir hayli avangard bir ekoldür, ne var ki, büyük şehirleri ele alışı, para-çıkar ve gayrişahsilikten öteye geçmediği gibi, kendi içinde bir hayli muhafazakârdır. Paranın toplumsal olgularla birlikte soyut olanı nasıl somuta tahvil ettiğini çalışmak yerine, paranın a priori kirliliğine takılıp kalmıştır. Park'ta, Burgess'ta, daha sonra Wirth'te çok duyacağımız bir soyutlama seviyesidir, para insanlar arasında ilişki kurar, gayri-şahsiliğin ve çıkarcılığın, menfaatperestliğin bir timsalidir (Park \& Burgess, 2015; Wirth, 1938). Nokta. Natüralizmin evrimci inşasının doksa yerine geçtiği bir teşkilatta, olguların soyutlanmaya değil, kavrandığı gibi açıklanmasına ihtiyaç vardır.

Park için anlam sorunu, olguların gerçeklikten ayrı bir fenomenolojisi olduğu fikri bir müşkilattır, çünkü "şüphesiz ki hayvanlar arasında en s1cakkanlı olanı insandır" (Park, 2015, s. 145), bu nedenle Polonyalı göçmen 
çocuklar bir semptomdur. Burgess için şehir bir metabolizmadır ve muhtemelen buradaki fikir metaforik değil, hakikaten onun bir metabolizma olduğunu kabul eden bir homolojidir. Kentsel büyüme anaboliktir (yapıcıdır) ve kataboliktir (yıkıcıdır)(Burgess, 2015, s. 99). Ne var ki bunda diyemeyiz, David Harvey'nin yaratıc yıkım (Castree \& Gregory, 2006) kavramıla aynı anlamı taşımıyor mu? Burgess, Chicago Okulu'nun sosyolojik yaklaşımını tanımlarken, onu bir cerrahi bilim keskinliğinde tasarlar. Harvey ise bambaşka bir geleneğe, diyalektiğe vurguda bulunur.

Chicago Okulu'nun atıfları sadece evrimsellikte ve organizmacilıkta kalsa, Chicago Okulu'nun ana eserleri sadece zamanının bir ürünü olmasıyla eleştirilebilecekken, yirminci yüzyılın ikinci yarısından sonra okurun yüzünün kızarmasına neden olabilecek Yahudilere, Siyahlara, Katoliklere, Polonya göçmenlerine, kadınlara ve daha bir yığın azınlığa ve dezavantajlı kesime yönelik en hafif deyimiyle kaba nitelendirmelerle, en kötü -ama açık-ihtimalle ırkçılıkla maluldür.

Bu nedenle, Andy Merrifield'ın Chicago Okulu'nun şehir karşıtı olduğu eleştirisine hak verebiliriz (Merrifield, 2002). Chicago muharrirleri şehirde yaratıc olanı değil, insan ekolojisinin habitatını görür. 1945'ten sonra şekil değiştirip nicel bir yaklaşıma bürünecek Chicago Okulu'nun ana metinlerinin lisans programlarında artık pek az okutulması, çalışmanın temel parametrelerini hazırlayan Şehir gibi kitaplarına çok az başvurulmasının belirli bir sebebi vardır. Savaş öncesi dönemden kalan büyük isimlere baktığınızda, örneğin Emile Durkheim'in İntihar metninin daha on dokuzuncu yüzy1lın sonunda $r$ k kavramının sosyolojik bir olgu olduğunu reddettiğini fark edebiliriz (Durkheim, 2002). Max Weber'in Protestan Ahlâkı'nda neredeyse bütün sektlerin ve tarikatlerin analizi yapılırken, ırk kavramına bir defa bile değinilmez (Weber, 1992). Robert Park'ın W.E.B. DuBois ile çalışmış olması, NAACP'nin kuruluşunda katkı sağlamış olması durumu pek değiştirmez (Park \& Burgess, 2015), 1945 sonrası değişen düşünsel düzlemin ayaklarının altından kaydığını çok geç fark edecektir Chicago Okulu. Talcott Parsons, Darwinizmi denklemden çıkarıp, yerine nicel bir sosyolojiyi kurduğunda, Albion W. Small ve Robert Park'ın düşüncelerini de Emile Durkheim ve Max Weber'in değişkenleriyle ikame edecektir (Parsons, 1968).

Beşerî ekoloji çerçevesini Chicago Okulu'nun elinden kurtarıp, yeni bir paradigmayı kuracak eleştiri Amos Hawley'den gelir. 1944 yılında yayınlanan yazısında, ekoloji yaklaşımının iki temel özelliği olduğunu tanımlar Hawley: rekabete dayanan bir biyolojizm ve mekânsal analiz. İlkini göz önüne aldığımızda diye ekler Hawley, ekolojistlerin rekabete dayalı etkile- 
şim dedikleri sadece "bir kavram hakkında tefekkürden fazlası değildir" ve bunu psikologlar daha iyi yapabilirler. Öte yandan, mekânsal analiz açısından baktığımızda ise beşerî ekolojinin çalışmalarının bir çoğu harita üzerinde toplumsal hayatın çeşitli özelliklerinin yansıtılmasından başka bir şey değildir, bu açıdan yaptıkları coğrafyacılığa benzer, ancak coğrafyacılarla kıyaslandığında kartografik yetenekleri çok daha aşağıdadır (Hawley, 1944, ss. 401-402). Bu ağır eleştiriden sonra Hawley ekolojiyi yeniden tanımlar: "ekoloji...kolektif hayatın morfolojisinin statik ve dinamik yönleriyle çallşılmasıdır (Hawley, 1944, s. 403). Bu nedenle, Hawley'e göre beşerî ekolojinin en basit tanımı "insan nüfusunun kendi fizikî şartlarına uyumunun tasvire dayalı çalışılmasıdır." (Hawley, 1944, s. 404) Bu çalışmanın dört ana ekseni vardır: 1. Değişmenin sürekliliği, 2. Toplumun nüfusunun büyüklüğü, bileşenleri ve büyüme veya düşüş oran, 3. Göçün önemi, 4. Toplumsal yapıyı oluşturan göreli rakamlar (Hawley, 1944, s. 405). Bu eleştiriyle, Hawley, daha sonra Brian Berry'nin de katkısıyla, ekolojik yaklaşımı evrimselci natüralizmin ellerinden kurtarıp, neredeyse tamamen nicelikten ve değişkenlerin rakamsal değerlendirmesinden oluşan bir yaklaşımın ana omurgası hâline getirecektir (Berry \& Wheeler, 2005; Feagin, 1987; Gottdiener \& Feagin, 1988).

\section{Büyük Kırılma: Manuel Castells ve Kent Sosyolojisine Tarihsel Materyalist Yaklaşım}

Manuel Castells'in kurucusu olduğu ve daha sonra bütün farklı hatlarıyla birlikte yeni kent sosyolojisi olarak adlandırılacak akım, varlığını ekolojik yaklaşımın evrimselci natüralizmi ve nicel yorumuyla kopuşa borçludur. 1968 y1lında, Castells, Y a-t-il une sociologie urbaine [Kent Sosyolojisi diye bir şey var mı?] makalesiyle bu kırılmanın parametrelerini tanımladı (Castells, 1968). Bu kısa ama kuramsal manifesto özelliğini hâiz yazı, Sociologie $d u$ Travail'ın Ocak-Mart sayısında yayınlandığında, daha Mayıs 1968 gerçekleşmemişti, fakat gelmekte olanı içinde taşıyordu.

Castells, yazısına Weber'den bir epigrafla başlar: "Yeni bir "bilim," yeni yöntemlerle yeni sorunların peşinden koşulduğunda ve orada gerçeklik keşfedilip önemli derecede yeni bakış açılarına imkân verdiğinde ortaya 
çıkar (Castells, 1976a, s. 33)."1 Castells mütevazı değildir, epigrafla yazının tonunu belirler. Castells'in müdahalesinden önce, kent üç farklı güzergâhta incelenmiştir, dünya çapında makro süreçlerin ürünü olarak kentleşme, toplumsal düzensizliklerin ve kültürlenme süreçlerinin ürünü olarak Chicago Okulu'nun yaklaşımı ve aslen etnolojiden kaynaklanan eski "toplum çalışmaları" deneyimi (Castells, 1976a, ss. 33-34). Ne var ki, Castells'e göre bu üç yaklaşım da kenti bilimsel bir nesne olarak tanımlayamamaktadır.

Çok daha sonra, çok daha büyük bir açk sözlülükle -"ben diğerleri gibi değilim, pozitivistim"- aktaracağ gibi (2006), Castells pozitivist bir manevrayla başlar. Kent bir bilimsel çerçeve içinde çalışılacaksa, kentsel bir bilim kurulacaksa, onun nesnesinin tanımlanması elzemdir. Kent sosyolojisi bir kuramsal bütünlük olarak yok olmaya yüz tutmasını kentin otonom bir toplumsal birim olmaktan çıkmasına borçludur (Castells, 1976a, ss. 35-36). Burada sorunlu olan mesele, aslında 1960'larda Castells' in eleştirisinin temelini pozitivizmin değil, bir tür ortodoksiye dönüşmüş Althusserci bilim anlayışından alıyor olması (Althusser, 1997, ss. 75-78). Althusserci hâle, çağrı [interpellation], ideoloji, her ne dersek diyelim, bir defa silindiğinde, geriye basit bir pozitivist mekanizma birakıyor.

\section{Castells ve Lefebvreci Müdahale}

Henri Lefebvre, doğrudan bu yazının konusu değil, çünkü bizim takip ettiğimiz yeni kent sosyolojisi alanının oluşumuna hem çok sonradan, hem de IJURR'un Britanyalı ve Fransız akademisyenleri eliyle değil, Amerika Birleşik Devletleri'nden katılacaktır. Ancak, burada, Althusser'e dair Les Paradoxes d'Althusser [Althusser'in Paradoksları] metnini kısaca hatırlatmakta fayda var (Lefebvre, 1969). Kopuş düşüncesine yaslanan, genç Marx-olgun Marx ayrımını yapan, Hegel'i Marksist düşünceden silen iki türlü yaklaşım vardır der Lefebvre bu ağır polemik yazısında. Birincisi eski dogmatik Stalinizm'dir ve bu cihet açısından kopuş felsefidir. İkinci tür dogmatizm ise yenidir ve varlığını Althusser'in yapısalcılık denilen düşüncesinden alır. Burada da kopuş epistemolojiktir. İlk tez substansiyalite [büyüklük] ile bilgi fetişizmi ve en nihayetinde devlet fetişizmiyle sonuçlanır, ikinci tez subjektivizm [öznellik] ile bilgiyi ve pratiği yok eder. Lefebvre, burada üçüncü bir tezden bahseder, kopuşun ne felsefi, ne de epistemolojik olduğundan, bu

\footnotetext{
${ }^{1}$ Aksi belirtilmediği müddetçe İngilizce' den yapılan çevirilerin hepsi bu satırların yazarına aittir.
} 
ikisinin gölgesinde kalan politika merhalesinde gerçekleştiğinden bahseder. İlk iki tür, Lasallecılığın içten içe Marksizmin yerini almasıyla ağır basmıştır (Lefebvre, 1969, ss. 4-7).

Henri Lefebvre'in 1970'lerde yeni kent sosyolojisiyle ilişkisi, Anatole Kopp ve François Choay'le birlikte kentsel biçim ve şehirciliğin tarihi üzerine önemli eleştirel metinler kaleme almış bir isim olarak anılmasından ibarettir (Topalov, 1989). Lefebvre, 1960'larda şehirciliğin teknokratların inisiyatifine terk edilmesine dair önemli metinler kaleme almıştır. Fakat Topalov'un 1965 sonrası Fransız sosyal bilimlerinin kente ve mekâna yaklaşımını irdelediği metninde, Henri Lefebvre, yabancılaşma ve şeyleşmenin filozofudur, kente ve o kapitalist kentselliğin içinde kurulan gündelik hayata dair eleştirileri dikkate alınmaz. Herbert Marcuse'yle beraber 1968'in öğrenci hareketi üzerinde çok büyük bir etkisi olsa da, Lefebvre'in katkıları "antihümanizm" destekçileri tarafından safiyane spekülasyon olarak değerlendirilir. Topalov'a göre Lefebvre, 1970'lerin Marksist kentsel araştırma alanı tarafından kayda değer bulunmayarak göz ardı edilir (Topalov, 1989, s. 630). Lefebvre, üstelik IJURR'a o kadar yabancı bir isimdir ki, 1980'lerin sonunda elle dizildiğini tahmin ettiğim dergide, kaynakçada doğru anılmasına rağmen, Topalov'un metni içinde editörler ve dizgiciler ismini Lefévre olarak birakırlar.

Öte yandan, Pierre Bourdieu'nün Fransız akademisinin ve düşünce dünyasının topografyasını çizdiği Homo Academicus metninde, Henri Lefebvre'in adı ne iki düzlemli mütekabiliyet analizinde, ne de Lire dergisinin yaşayan düşünce dünyasının büyük hocaları anketinde anılır (Bourdieu, 1988). Lefebvre'in eleştirel kentsel düşünceye ve "alan"a dahli, daha sonra, 1980'lerde David Harvey, 1990'lar ve 2000'lerde ise Neil Brenner, Erik Swyngedouw, Kanishka Goonewardena ve Maria Kaika gibi isimlerin sayesinde gerçekleşecektir (Brenner, Jessop, Jones, \& Macleod, 2008; Goonewardena, 2005; Kaika \& Swyngedouw, 2000; Swyngedouw, 2002).

Castells, eski hocası Henri Lefebvre'e 1970'lerin başında yayınlanan Le Question Urbaine'de [Kent Sorunu] uzunca bir eleştiri vakfeder. Daha erken tarihli yazılarında üstü örtük biçimde eleştirel ama açıtan övücü satırlar (Castells, 1968, 1976b), 1970'lerde “kentsel kırılma"nın esas itkisini sağlayan Le Question Urbaine'de yerini Lefebvre'in mekânı fetişleştirdiği, "kentsel olgunun Marksist analizi" diye başladığı işi "Marksist sorunsalın kentsel kuramı"yla bitirdiği iddiasına bırakır (Castells, 1977, s. 87). Kentin ve kentsel olanın sembolik düzlemde çalışılması, kentsel semiyolojinin tehlikeli bir eğilimidir. Kent, langue ve parole üzerinden değil, Althusserci ideolojinin 
kentsel dolayımla kavranmasıyla çalışlabilir (Castells, 1977, s. 220). Lefebvreci hümanizm, metafiziktir ve en nihayetinde mekânın taşıdığı özgürleşme sorunu Marksizmin iştigâl alanı değildir, olsa olsa felsefenin ya da dinin (ilahiyatın) ilgi alanına girer (Castells, 1977, s. 92).

Marksist literatürü yakından tanıyan herhangi birinin tahmin edebileceği üzere polemik alanında, Althusserciliğin pek sevdiği tanımlamayla, "kuramsal pratik"te (Althusser, 1977, 1997), en affedilmeyecek günah, en ağır suçlama, böylesi bir fetişizmdir. Alanın, "kuramsal pratik"e mütekabiliyeti burada ele alınamayacak kadar çetrefilli bir meseledir; ne var ki, Marksist alanın kendi edimsel biçimler, önkabulleri, polemik düzeyleri, yanlışlama ve yanlışlanma kapasitesi ve en nihayetinde de kendine dair bir metakuramı mevcuttur. Bunun ne kadarının doksayla ilintili olduğu, ne kadarının alanın inşasıyla yakından temas ettiği, alan dediğimiz şeyin tarihselcoğrafi dönüşümüyle belirlenir.

Pekiyi Castells, kenti bir nesne olarak tanımlama ve böylelikle mekâna dair bilimi yeniden kurma iddiasını nereye veya neye dayandırır? Chicago Okulu'nun şehri iki kavramsal düzlemde tanımlamasının -düzensizliğin laboratuvarı ve sosyolojik değişken- aksine aslında "şehircilik" [urbanism] tahayyülünün kapitalist sanayileşme sürecinin bir ürünü olduğunu iddia eder (Castells, 1976a). "Şehir, tarihin ta kendisinin ürünüdür, toplumun yansımasıdır, kendi meskenini inşa eden İnsan'ın mekândaki eylemidir. Böylece, kent sosyolojisi insanlığın geleceğiyle ilişkilidir (Castells, 1976a)." Bizim yapmamız gereken diye ekler Castells, kentsel davranış, kentsel yaklaşımlar gibi kavramları kullanmayı bırakmak olmalıdır, çünkü bu kavramların bizâtihi kendiler bir kentli kültürü varsayarlar. Oysa bu kültür sanayileşmenin ve belirli bazı durumlarda da kapitalist sanayileşmenin doğrudan sonucudur. Ne yapmalı sorusunun cevabı bellidir: şehir olduğu gibi çalışılmalıdır (Castells, 1976a).

Ve bu şehri bir çalışma nesnesi hâline getiren, onun bilimsel bir nesne olmasını sağlayan, sadece şehre özgü bir ekonomi-politik gerçekliktir: "kolektif tüketim." Toplumsal hareketler, kentten neşet eden siyasi faaliyetler, mekân üzerindeki arz ve talep yönlü baskılar, kısitlı kaynaklar üzerindeki hak talepleri, artı-değerin bölüşümü üzerindeki iddialar, bütün bunları kentin yörüngesine yerleştiren "kolektif tüketim"in sadece ve sadece kentte nesneleşmesidir. Daha doğrusu, kenti, yeni kent sosyolojisinin nesnesi kılan, "kolektif tüketim"in sadece orada gerçekleşmesidir (Castells, 1977).

Kolektif tüketimin kentsel nesneyi tanımlamasının yanı sıra Weberci devlet analiziyle Marksist sınıf yaklaşımını harmanlayan Ray Pahl'ın çalış- 
maları (Pahl, 1969; Pahl, 1977), Jean Lojkine' in kapitalist kentleşme kuramlarını 1960'ların yeni sol merceğiyle yorumlaması (Lojkine, 1976), Chris Pickvance'ın farklı Marksist yorumların içinde daha ziyade CastellsAlthusserci çizgiyi belirleyici müdahalesiyle (Pickvance, 1978), yeni bir kentsel bilimin ana hatları ortaya çıktı. Uluslararası Sosyoloji Derneği [International Sociological Association] bünyesinde 21 numaralı Araştırma Komitesi (RC21) Chicago Okulu'na ve nicel yaklaşımların hegemonik hâkimiyetine bir tepki olarak 1970'de Uluslararası Sosyoloji Birliği'nin Varna Kongresi'nde 53 üyenin desteğiyle kuruldu (Milicevic, 2001, s. 768). 1977 yllinda ise RC21, International Journal of Urban and Regional Research dergisini yayınlamaya başladı. Bu sayede, Castells'in muştuladığı yeni kent bilimi alanınin nesnesine dair incelemeler kendine ait bir temsil mahali buldu.

\section{Alanı Tanımlamak, Sınırlan Çizmek: IJURR ve Yeni Kent Sosyolojisi}

IJURR'un ve yeni kent sosyolojisinin bir alan olarak ortaya çıkışından nispeten kısa süre sonra bu alanı konu edinen temel meta-kuramsal metinler de üretilmeye başladı. Bunlardan ilki ve en bilineni Sharon Zukin'in daha yeni kent sosyolojisinin itirazı gayet canlıyken 1980'lerin başında yazdığı metin (Zukin, 1980). Ayrıca, biri 1989'da Christian Topalov tarafından diğeri de 2001'de Sasha Milicevic tarafından yazılan ve IJURR'da yayınlanan iki makaleyle de derginin kendi meta-kuramsal değerlendirmesini yaptığını söyleyebiliriz (Milicevic, 2001; Topalov, 1989).

Bu iki yazıdan daha eski tarihli olanı, Fransız kuramsal tartı̧malarının ve esasında entelektüel alanının oluşumu ve dönüşümünün yeni kent sosyolojisini hangi sâiklerle kurduğunu inceler. Topalov, yazısında, bir entelektüel izlek eşliğinde, eleştirel mekânsal düşüncenin 1960'lardan itibaren hangi tartışmalardan beslendiğini aksettirir. Aynı zamanda, Topalov'un yazısı Bourdieu'nün bahsinin geçtiği -1980'lerde yayınlanan Edmond Preteceille'in iki makalesi ve bir uluslararası konferans notundan sonra- en erken tarihli makalelerdendir.

Topalov, 1975-1987 arasında Fransız kentsel araştırmalarının bir duraklama sürecine girdiğini, bunun FKP'nin çökmesi gibi siyasi sebeplerinin olduğu gibi, Dögolcü kalkınma planlarının 1974'te Giscard d'Estaing'in, 1981'de de François Mitterand'ın seçilmesiyle rafa kaldırılması gibi daha ziyade kamu yönetiminin yapılanmasına yönelik tercihlerle de ilgili olduğunu belirtir. Sharon Zukin'in altını çizdiği, daha sonra Sasha Milicevic'in mülakatlarında duyacağımız bir tema Topalov'da da mevcuttur: Marksist 
kent çalışmaları 1970'lerde kapsamlı bir kentsel krizin gerçekleşeceğini öngörmekteydi. Alanın kuruluşu, bu gelmekte olan krize dair değiştirici ve şekillendirici bir kaygı taşıyordu. Kriz gelmedi. Ekonomi-politik düzlemde gerçekleşen kriz, 1968'de Martin Luther King Jr. suikastinden sonra ABD'nin metropolitan şehirlerinde yaşanan ayaklanmalara benzer bir tepkiye yol açmadı (Milicevic, 2001; Zukin, 1980).

Şehre kriz gelmedi ama yeni kent sosyolojisine kriz geldi. Topalov, bu krizden çıkış için farklı yeni çalışma sahalarından bahseder. 1970'lerde araştırma sorunları siyasi değişim etrafında şekillenmekte iken, 1980'lerde başat sorunsal toplumsal yeniden üretimdir. Bu istikamette birinci sorunsal bizâtihi kriz meselesi ve 1970'lerin sonundan itibaren değişmekte olan ücret yapısıdır. İkinci sorunsal siyaset meselesi, siyasetin nasıl çalışılacağına dair, 1970'lerdekinin aksine kestirmeci olmayan bir çerçeve üretebilmekle ilintilidir. Burada Topalov, Gramsci ve Gramscici bir yerden Jean Lojkine'le Edmond Préteceille'in çalışmalarını anar. Üçüncü sorunsal, iktidar meselesidir, tabii ki bu hususta Michel Foucault'nun çalışmaları belirleyicidir. Dördüncü sorunsal, pratikleri ilgilendirir, işte bu aşamada Bourdieu ilk defa anılır. Topalov, Pinçon ve Pinçon-Charlot'nun çalışmalarından bahsettikten sonra, gündelik hayat pratikleriyle ilgilenen bir çerçevenin gerekliliğinin altını çizer. Sorun şudur, sıradan kültürcülüğün totolojilerine kapılmak epeyi kolaydır. Bunu aşmayı sağlayan ise Pierre Bourdieu'nün yapıtıdır (Topalov, 1989, ss. 639-643). Aynı soruyu Topalov'la aynı sayıda yayımlanan bir diğer makalede Ray Pahl da sorar, ancak onun verdiği cevapta henüz daha Bourdieu'ye yer yoktur. Pahl ile Topalov bir noktada buluşmaktadırlar, sınıfın herşeyi izâh eden bir kavram olması yetersizdir, sorunludur, eksiktir. Fakat Pahl'a göre sınıfı kavramsallaştırmak üzere E.P. Thompson'ın yapıtına geri dönmek gerekir (Pahl, 1989).

Topalov'dan on iki yıl sonra, Sasha Milicevic, Radical Intellectuals: What Happened to the New Urban Sociology? [Radikal Entelektüeller: Yeni Kent Sosyolojisi Nereye Gitti?] isimli bir makale yayınladı. Makale yöntemsel açıdan daha önce yazılan makalelerden bir hayli farklıdır, çünkü ilk defa yeni kent sosyolojisini bir "alan" olarak ve bir sosyolojik nesne olarak çalışmaya gayret eder. Sosyolojinin kendisi, kendine dönük bir nesne olmuştur artık. Her nesneleşmenin düşünsel ürününde rastlandığ1 gibi somuttan soyuta geçiş aşamaları sorunludur. Teorinin kendisini bir parametreye çevirdiğinizde nüanslar silinir: Manuel Castells'le David Harvey'nin aynı zamanda aynı güzergâha yöneldiği, ikisinin de postmodernizmle iştigâl etmeye başladığı gibi bir anlam çıabilir (Milicevic, 2001, s. 762). 
Milicevic, yeni kent sosyolojisini bir sosyolojik nesne olarak ele alırken iki yaklaşımdan faydalanır. Birincisi, Alvin Gouldner'ın akademisyenler arasında 1960'lardan sonra gelişen radikalizme dair kuramıdır. Gouldner' ın iktidar ve bilgi arasındaki ilişkiye dair tahlillerinden, özellikle akademinin profesyonelleşmesi ve devletle akademi arasında gelişen simbiyotik ilişkiye dair eleştirisinden faydalanur (Milicevic, 2001, ss. 760-761).

İkinci yaklaşım Gouldner'inki kadar baskın olmamakla birlikte, Bourdieu'nün alan kuramıdır ve "Yeni Kent Sosyolojisi" de üniversitelerde mevcut bütün diğer alanlar gibi bir alandır. Burada, Milicevic, Bourdieu'nün de esasında bir hayli sarkastik imâsını tekdüzeleştirir. Aşağıda vurgularla verilen Milicevic'in kısa alıntısının işaret ettiği gibi Bourdieu sadece, üniversite diğer alanlar gibi bir alandır ve hiyerarşisi vardır demez. Bourdieu, akademide çatışan hiyerarşiler mevcuttur der:

Nouvel Observateur'de yazmak gibi kimilerinin öne çkaracağı ve kamusal olarak övünebileceği bir durum başkaları tarafından kendilerine özgü dünyalarında stigmata olarak algılanır ve o dünyadan dişlanmaya neden olur (bu hayali bir vaka değil, gerçektir). Böylesi mükemmel ters-yüz olma vakalarında, yani birinin üstünlük imtiyazının diğeri için kötü şöhretli olmak anlamına gelmesi, birinin üstünlük alametinin diğeri için hakaret demek olması, bize, üniversite alanının, başka herhangi bir alan gibi, meşru üyeliğin ve meşru hiyerarşinin kriterlerini belirlemek üzere bir mücadele yeri olduğunu, yani, hangi özelliklerinin ilgili, etkili ve alanın gerektirdiği belirli kârları sağlamak üzere sermaye olarak işleyebileceğini gösterir (Bourdieu, 1988, s. 11).

Bourdieu'nün meselesi, akademinin içinde rakip hiyerarşilerin var olması, bu hiyerarşilerin alanın inşasında nasıl kurulduğunu, nasıl dışlama ve içerme mekanizmalarıyla hareket ettiğini göstermek, sosyolojik analizden münezzeh olduğu addedilen akademik iştigâl alanının sosyolojisinin yapılmasını sağlamaktır.

Bourdieu, bireyin, kişinin inşa edilmiş olduğu bir akademik alandan bahseder - daha sonra, kendisinin muris rolünde buna atıfta bulunacağız. Basitçe, "bilimsel analiz tarafından inşa edilmiş Lévi-Strauss" der Bourdieu, "Tristes tropiques'in yazarı olan" Lévi-Strauss değildir (Bourdieu, 1988, s. 22). Burada yapısalcılığı barizdir, Lévi-Strauss bu inşanın parçası olarak anıldığ müddetçe fiziksel gerçekliğinden ayrı bir karakterdir. Doksanın alanının, yani doksik mekânın, parçasıdır o artık. Bu ân, epistemik bireyle gerçek bireyin ayrıldığı noktada ortaya çıkar.

Bourdieu için akademisyenin konumlandığı mekân, Lévi-Strauss üzerinden mükemmelen tanımladığı mütekabiliyet analizinde belirginleşir. 
Lévi-Strauss nispeten dışarlıklıdır, akademik dünya üzerindeki hiyerarşik ve disipliner kontrolü fevkalâde kısıtliyken düşünsel etkisi o raddede güçlüdür (Bourdieu, 1988, s. 276). Bourdieu'nün yolu, burada, Lévi-Strauss'a bir daha uğrayacaktır, Homo Academicus'un sarkazmının yöneldiği en önemli eklerinden birinde Lire dergisi tarafindan yapılan araştırmada, hâlâ yaşayan üç kişinin - Gide, Camus ve Sartre gibi büyük etki sahibi üç entelektüel hocanın, - sıralanması istenir ankete katılan 448 akademisyenden. Birinci sırada Claude Lévi-Strauss yer alır, onu Raymond Aron ve Michel Foucault takip eder. Bourdieu'nün kendisi 10 oyla 36. sırada yer alır (Bourdieu, 1988, ss. 261-268). Bourdieu, sadece Lévi-Strauss'un doksaya özgü ve epistemik karakterinin ayrışmasına dikkat çekmesiyle değil, ileride bahsedeceğim gibi kendi mekânsal tahayyülünü kuran Berber evleri hakkında yazdıklarıyla da Lévi-Strauss'un Bororo köylerinin varisidir (Bourdieu, 1970; Lévi-Strauss, 1955, ss. 254-255).

Milicevic, öte yandan, Gouldner'ın ve daha sonraki müteakip çalışmaların mükerrer sorununa, söylemi içerikten ayırma yanılgısına düşer. Milicevic'in analizinde Bourdieu sadece geçerken bir uğrak noktasıdır. Bu yeni kent sosyolojisinin sosyolojisi analizinde, Gouldner'ın kuramı sadece hegemonik konumdakilere karşı bir manivela, bir silah olarak kullanmaya indirgemesi, muhalif konumdakilerin iktidar elde etmesine kadar süren geçici bir manevradır. Yeni kent sosyolojisi bir kuşak hareketidir ve radikalizmi iktidar konumunu elde ettikten sonra sönümlenmiştir (Milicevic, 2001, ss. 773-774).

Milicevic'in olgusalcı/objektivist natüralizme kayan meta-sosyolojisinin ayna imgesi, hemen hemen aynı yıllarda yazılan bir başka kitapta kendini parlak bir biçimde gösterir. Sosyolojik değişkenlerin yerini söylemin yapıtaşlarının aldığı Greig Crysler'ın, Writing Spaces: Discourses of Architecture, Urbanism, and the Built Environment, 1960-2000 [Mekânları Yazmak: Mimarlık, Şehircilik ve Yapılı Çevre Söylemleri, 1960-2000] kitabı. Crysler, burada beş dergiyi ele alarak, bu dergilerin mekânı nasıl söylemsel seviyede kendi alanlarına mündemiç kıldığını çalışır (Crysler, 2003). Crysler'ın mekânın tahayyülü açısından belirleyici kabul ettiği bu beş dergi: The Journal of the Society of Architectural Historians, Assemblage, Traditional Dwellings and Settlements Review, International Journal of Urban and Regional Research ve Environment and Planning D: Society and Space'tir. Crysler'ın çalışması, başlangıcını Hayden White'ın yaptığı bir söylem analizi tasavvuruna dayanır (White, 1973, 1978). White, 19. yüzyıl düşüncesinin gelişimini Gaston Bachelard mülhem bir entelektüel/poetik yöntemle anlamaya çalışırken, bu poetik 
dilin dört temel trope'u olduğunu öne sürecektir: metafor, metonimi, sinekdoş ve ironi (White, 1973, s. 10).

Crysler, 1990'larla birlikte IJURR'da iki değişimden bahseder. Birincisi, 1977 ve 1987 arasında yayınlanan ve kentsel toplumsal hareketlerle akademi arasında bir köprü kurmaya girişen Praxis kısmının yayınına son verilmesidir. Bu nedenle, derginin Gramscici organik entelektüel oluşturma gayesi sekteye uğramıştır. İkincisi, doğrudan birinci değişimin sebebidir, kolektif tüketimin devlet tarafından sağlanması ortadan kalkınca, akademi dışındaki siyasi hareketlerle bağ kesildiği gibi, derginin editörleri 1998 yılında yayınladıkları bir editoryal yönelim yazısıyla toplumsal değişime dair konumlarının salt analitik bir konum olduğunu ifade ederler (Crysler, 2003, s. 201). 1990'larda başlayan bu dönüşümde, Manuel Castells'in de kentsel düşüncenin sularından ayrılması ve enformasyon toplumu hakkında çalışmalara dönüşecek bir seri eser vermesiyle, IJURR'un da bir alan olarak yeniden üretimi farklı bir aşamaya girer. İşte bu aşamada, Pierre Bourdieu'nün etkisi çok daha belirgin bir hâle gelir.

\section{Bourdieucülüğün Alandaki Gelişimi}

1977'de çıkarılmaya başlanan International Journal of Urban and Regional Research, 42 yıl içinde, EBSCOHOST Sociology Source veritabanına göre 2269 makale yayınlamıştır. Bu makalelerin 130'unun ana metin içerisinde Bourdieu'ye gönderme yaptığını görebiliyoruz. Bu rakam bütün makalelerin yüzde 6'sından biraz azı. 1990'dan bu yana yayınlanan makalelerin içinde Bourdieu'ye attfta bulunan makale sayısı, yüzde 7'nin biraz altında kalırken, 2000 yılından beri yayınlanan makalelerin yüzde 8'i Bourdieu'ye referans veriyor. Son on yılı düşündügüumüzde, bu sayı yüzde 8 'in hemen üzerine çıııyor. 2018 başından itibaren iki özel sayının Bourdieu eksenindeki çalışmalara ayrıldığını göz önüne alırsak, sayının artmaya devam edeceğini tahmin edebiliriz (EBSCO, 2019).

Bir karşılaştırma olması açısından, Bourdieu'ye atıfta bulunan makale sayısıyla, IJURR ekolünün kurucu figürünü karşılaştırmakta fayda var. Manuel Castells, 42 yıl içinde 380 makalenin tam metninde anılmış. Bu makalelerin 108'i 1977-1990 yılları arasında yayınlanmış, aynı dönemde Bourdieu'ye göndermede bulunan makale sayısı sadece 6. Son on yılda, 20082018 arasında, Castells'e referans veren makale sayısı 98 iken, Bourdieu'ye göndermede bulunan makale sayısı 81 (EBSCO, 2019). 
Rakamlara göz atmanın şöyle bir faydası var; paradigmanın içinde olanlar, nitel yer değiştirmeleri, kavramların semiyotiğini gerçekte olduğundan daha yakın, olguların dönüşümünden daha belirgin yorumlayabilirler. Bilginin hermenötiği bu nedenle hâlâ önemli bir kavram olmakla beraber; gerçekliğin rakamsal ifadesi, bilginin alımlanışı ve yorumsamasına dair ara katmanı devreden çıkarıp, heuristik olgunun, hermenötiği düzeltmesine yarayabilir.

IJURR'da Bourdieu'ye bir atifta bulunan ilk makale Edmond Preteceille'in Fransa'da sol belediyeciliğin kısıtlılıklarını anlatan 1981 tarihli yazısı. Preteceille, yeni kent sosyolojisinin kurucu figürlerinden ve ayn zamanda aktif bir araştırma kurumunun 1970'ler ve 1980'ler boyunca başında bulundu. Jean Lojkine'le birlikte Marksizmin kentsel düşünce içerisine nüfuzunda son derece etkin ve Britanyalı kent araştırmacılarıyla faal iletişim içinde olduğundan ötürü de Anglofon dünyada tanınırlı̆̆ yüksekti. Yazının yayınlandığ1 yıllarda Centre de Sociologie Urbaine'de Monique Pinçon ve Paul Rendu ile birlikte Paris bölgesinde kentsel hizmetlerin sağlanması ve yerel idarenin rolü hakkında bir araştırma yürütmekteydiler (Preteceille, 1981, s. 413). Birlikte yürüttükleri araştırmaya ilaveten, Preteceille, Pinçon'un Pierre Bourdieu'nün La Distinction'undan [Ayrım] etkilenerek yazdığı makalelerden bahseder (Preteceille, 1981, s. 417). Pinçonların, Bourdieu'nün araştırma ajandasını ve kuramsal yaklaşımını kentsel araştırmalara taşıyan ender isimlerden olduğunu daha sonra Loic Wacquant da yazacak, fakat tarihlendirmeyi 1980'lerin başı yerine 1990'ların başında konumlandıracaktır (Wacquant, 2018, s. 91).

Preteceille'in bu görece erken tanıştırma çabasına rağmen, 1980'ler boyunca IJURR'un satırlarında Bourdieu çok ender anılır. 1983 tarihli ve kentsel değil, Avrupa'daki kırsal dönüşüm ve bu dönüşüme karşı verilen mücadelelerden bahseden bir yazıda Bourdieu'ye değinilir (Mormont, 1983). 1980'lerin sonuna gelinirken, 1988 tarihli ve Birinci Uluslararası Tüketim Sosyolojisi Konferansı'nın özeti ve eleştirisini yapan Bob Holton'ın yazısında -doğal olarak- Bourdieu'den bahsedilir (Holton, 1988).

Tüketim sosyolojisi ve sosyal sermaye ekseninde ekonomi sosyolojisi çalışmaları Bourdieu'nün Anglofon dünyada hemen hemen en önemli eserlerinin çevrildiği anda hak ettiği ilgiyi bulduğu alanlardır (Swedberg, 2011). Ne var ki, kent sosyolojisi, daha hâlâ "yeni" sıfatını taşıdığı yıllarda bu kadar hizlı hareket etmeyecektir. IJURR'da bütün 1980'ler boyunca Bourdieu'ye değinen sadece dört yazı basılır. 
1990'lar, Crysler'ın da işaret ettiği gibi derginin editoryal politikasının klasik Marksist araştırma güzergâhını terk edip, özellikle üretim coğrafyalarından tüketimin parametrelerine yöneldiği yıllar olacaktır. 1990'ların ilk yıllarında peş peşe yayınlanan beş makalede (Ducatel \& Blomley, 1990; Mullins, 1991; Norclilffe, 1993; Smart \& Smart, 1991; Warde, 1990), perakende tüketimin sermayesinden, Hong Kong'un Güney Çin'deki yatırımlarıyla gelişmesine, turizm aracllığyla kentleşmeden, kitle üretiminin esnek üretime dönüşüne ve Peter Saunders'in tüketim hakkındaki yaklaşımlarına dair yazılarda Bourdieu'nün çalışmaları ve izleri belirginleşmeye başlar.

Kirılma noktasına yönelik ilk hamle Loic Wacquant'in 1993'te yayınlanan Urban Outcasts yazisiyla gelir (Wacquant, 1993). Wacquant'in Siyah Amerikan ghettosunu ve Fransız banliyölerindeki dışlanma süreçlerini aktardığı bu yazının yayınlandığı sayıda Herbert Gans ve Enzo Mingione'nin de kentsel dışlanma süreçleriyle ilgili yazıları yer almaktadır. Wacquant, 1980'lerin ortasından itibaren Amerikan sosyolojisi içinde bir Bourdieucü interlocutor/aktarıcı karakteri kazanmıştır, 1989'da Sociological Theory'de yayınlanan Bourdieu'yle hayli kapsamlı bir mülakatın ve bu mülakatın girişini teşkil eden ağır bir eleştiri yazısının da müellifidir (Wacquant, 1989).

Wacquant, Urban Outcasts'te Bourdieu'nün Fransiz banliyölerine dair tek bir makalesinden faydalanmıştı (Bourdieu, 1991). Makale, Bourdieu'nün kentsel düşünceye ne katabileceği gibi meta-kuramsal bir yaklaşımda bulunmaktan ziyade, bir nevi karşılaştırmalı sosyolojide ısrar eder. Amerikan ghettosuyla Fransız ghettosu arasında bir bağlantı kurarak yeni bir tür sosyolojiye, olgusal olanın yoğunluğu ve gerçekliğiyle yoğrulmuş bir yaklaşım biçimine çağırmaktadır. Mahut Wacquant kritiği burada da belirgindir, yoksulluk istatistiklerle, gelirle, hayat standartları karşılaştırmasıyla, tüketim örüntüleriyle algilanabilecek bir mesele değildir. Ve bütün bunlar aslında bürokrasilerin ve prosedürlerin -bizâtihi bu ölçümleri yaratanların- kendine has özelliklerinden başka bir şey değildir. "Yeni kentsel yoksulluk" ancak onu yaşayanların deneyimleri üzerinden kavranabilir. Segregasyon ırksallaştırır ve devlet buna müsaade ettikçe kentsel mülksüzleştirmeyi hızlandıracak ve kentsel dışlanmanın objektif ve subjektif gerçekliği içinde yaşayan kent dışlanmışları radikalleşeceklerdir (Wacquant, 1993, s. 380).

Wacquant'tan sonra, Bourdieucü yaklaşımların hızı beklendiği gibi artmadı. Ne kentsel yoksulluk çalışmalarında, ne de kentsel etnografya alanında davet edilen "düşünümsel sosyolojiye"ye (Wacquant, 1989) icabet edildiğini söylemek mümkün. Bourdieu'nün özellikle La Distinction'da daha önce üzerinde düşünülmeyen sınıf fraksiyonları ve tüketim örüntüleri bağ- 
lamında yeni bir orta sınıf -allodoxia'ya tabî sınıf- oluşumunu incelemesi New York'ta, Londra'da ve Paris'te şehiriçi yerleşim alanlarında soylulaştırma (Carpenter \& Lees, 1995) ve yeni konut mimarileri ve bunların habitusları üzerinden şekillenen tüketim alışkanlıkları (Podmore, 1998) gibi çalışmalarda gösterge teşkil etti.

1990'ların muzaffer küreselleşme literatürü içinde Bourdieu'nün kavramsal kümesinin önemli öğelerinden birisi olan sosyal sermaye, Dünya Bankası'nın neoliberal kalkınma inisiyatifinin bir parçası hâline geldi (Grootaert, Narayan, Jones, \& Woolcock, 2004; Grootaert \& Van Bastelar, 2002; Woolcock \& Narayan, 2000). Tabii, Bourdieucü sosyal sermaye ve Dünya Bankası uzmanlarının anladığı sosyal sermaye arasında isim benzerliğinden başka bir ortak nokta olmamasının altını çizmek gerekir. Robert Putnam ve Alejandro Portes'in kavramsallaştırdığ 1 cihetten sosyal sermaye (Portes, Castells, \& Benton, 1989; Putnam, 1995), küreselleşmenin hegemonik dilini kuranlar açısından, Oscar Lewis'in (Lewis, 2011) sorduğu soruya yanıt vermeyi başarıyordu: Neden yoksullar yoksul kalmaya devam ediyorlar? Çünkü sosyal sermayeleri yok, bu nedenle onlara refah devletinin imkanları yerine, önce muteber fertler olmayı öğretmemiz gerekiyor.

Bourdieu'nün sosyal sermayesinin bu şekilde tasvir edilmediğinin altını çizmeye gerek yok; salt Wacquant'ın Urban Outcasts'i ve La Distinction bile sosyal sermayenin ekonomik dışlanmayı anlamlandırma çabası olduğunu ortaya koyuyor. Ne var ki, 1990'ların sonunda ve 2000'lerin başında Bourdieu'nün kavram kümesini sosyal sermaye ve enformel ekonominin toplumları dönüştürme kudretini açıklama işine koşan, bir kısmı burada serdettiğimiz eleştirileri dile getiren bir dizi araştırma yayınlandı (Fernández Kelly, 1994; Mayer, 2003; Sik \& Wallace, 1999; Thuen, 1999; Wallace, Shmulyar, \& Bedzir, 1999).

2000'lerin başı, Bourdieu'ye doğru çubuğun kesin olarak büküldüğü bir araştırma ve yayın akışına işaret ediyor. Kentsel dönüşümün artık gözle görülür bir biçimde soylulaştırmaya dönüştüğü, şehir merkezlerinin eski konut stoğunun yenilenip "yeni" orta sınıfın gösteriş̧̧i tüketim nesneleri ve hayat tarzı emarelerine dönüştüğü ve küresel sermayenin "iş hizmetleri" sektörüyle yayıldığı zamanlarda, Bourdieu'nün La Distinction'la geliştirdiği araştırma çerçevesi büyük rağbet gördü. Bu nedenle, soylulaştırma [gentrification] kavramı Bourdieu'ye yapılan atıflarda IJURR'da önemli bir ilinti sağladı (Bridge, 2001; de Decker, Kesteloot, de Maesschalck, \& Vranken, 2005; Degen, 2003; Martin, 2005). 


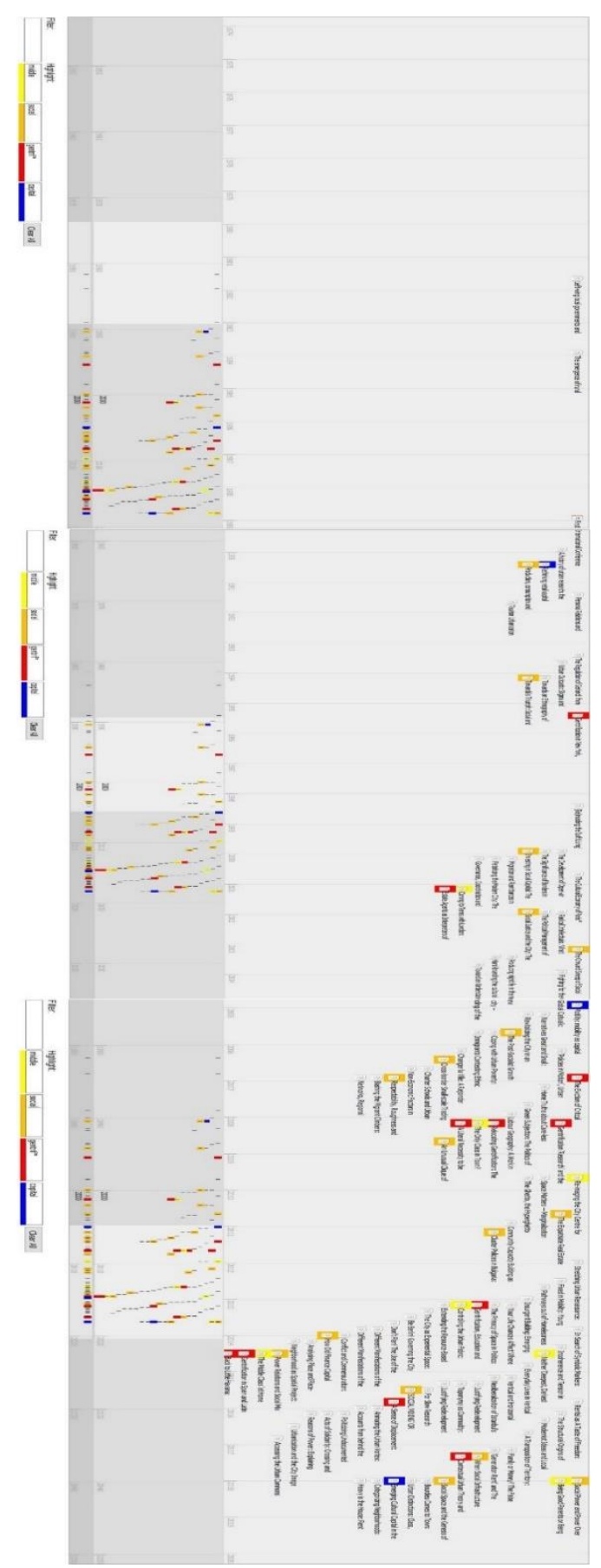

Şekil 1. IJURR' da tam metinde Bourdieu'den bahseden makalelerin zaman dizini. 
Soylulaştırmaya yönelik bu büyük akademik ilgi, beraberinde nispeten şiddetli bir polemiği de getirdi. Tom Slater'ın 2006 yılında soylulaştırmaya yönelik kent çalışmalarının nasıl eleştirel yaklaşımlardan mahrum kaldığını açıkladığı ve soylulaştırma literatürüne bu denli olumlu yaklaşmaya dair ağır eleştiriler içeren yazısı, Paul Watt'ın ve en nihayetinde Loic Wacquant'in destekleriyle bir nevî istikamet düzeltme işlevi üstlendi (Slater, 2006; Wacquant, 2008; Watt, 2008). Bu tartışmanın detaylarına girmeyeceğim, fakat, bu tartışmanın içinde Wacquant'ın üstlendiği interlocutor/aktarıı işlevinin önemli bir yeri var.

Slater ve Watt, Bourdieu'de işçi sınffına dair çözümlemelerin ve analizlerin orta sınıfa yönelimi kadar yoğun olmadığı yönünde üstü kapalı eleştiriler getirdiler (Slater, 2008, s. 220; Watt, 2006, s. 777, 2008, s. 206). Her ne kadar dipnottan veya hafif dokundurmalardan daha öteye geçmeyen eleştiriler olsa bile, Wacquant'in polemiğe müdahalesi Slater'in provokasyonunu aşan bir kuvvette gerçekleşti. IJURR'un sayfalarında 2000'li yıllarda başl1ğında sınıf geçen sadece tek bir makaleye yer verildiğini, yayınlanmış yazıların çok büyük bir kısmının Bourdieu'yle birlikte yazdıkları Neoliberal Newspeak [Neoliberal Yenikonuş] metninde geçen "küresel/leşme, yönetişim, dışlama, ölçek, toplumsal hareket, network, işletme ve etnisite" gibi neoliberal yenikonuşun olmazsa olmazlarıyla örülü olduğunu yazdı (Bourdieu \& Wacquant, 2001; Wacquant, 2008, s. 200).

Bu yazıyı yazmamda başlangıç noktasını oluşturan ve IJURR'un satırlarında Bourdieu'nün izlerini aramak fikrini de veren yazısında Wacquant, eleştirel eleştiriyi de eleştirerek, sınıf analizini yeniden canlandırmaya ve revize etmeye davet çağrısında bulundu. Yirmi birinci yüzyılın soylulaştırılmış mahalleleri "iktisadi olarak altbelirlenmiş ve siyasi olarak üstbelirlenmiş" dir saptamasında bulunan Wacquant, doğrudan Althusser'e yapılan bu göndermeyle, son kertede kentsel mekânın siyasi olarak oluşturulduğunu, iktisadın ise ikincil rolü aldığının vurgusuyla devletin sosyomekânsal eşitsizliğin temel üreticisi olduğuna işaret etti (Wacquant, 2008, s. 203).

Wacquant'in bu polemikteki hamlesi, radikal olanı radikalleştirmek gibi ilginç bir tavır. Zira, son kısımda açıklayacağım üzere, Bourdieu'nün 1980'lerde mekâna müdahalesinin ciddi bir omurgasını sınıf analizinin yerine grupların alandaki çoklu ilişkilerine eğilmeye yönelik çağrı oluşturdu. Öte yandan, IJURR'da Wacquant'in bu yazısından sonra bir çizgi değişikliği olduğu, kentsel mekânda neoliberal müdahaleye dair çok daha canlı bir eleştirel araştırma gündeminin oluştuğunu iddia edebilirim. Bu nedenle, 2000'lerin sonunu, Büyük Resesyon'un etkisiyle birlikte neoliberal yenikonu- 
şun yerini eleştirel bir kent sosyolojisinin aldığı ve Bourdieu'nün de Castells'i alandaki hegemonik modus operandi'nin kurucu figürü olarak ikame ettiği bir zaman dilimi olarak tarihlendirebiliriz.

Modus operandi'nin kurucu figürü olmak, alanın sınırlarını ve işlemselliğini belirleyici bir otorite kazanmak göründüğünden çok daha zor bir iş. E.P. Thompson ve Neil Smith iki belirgin örnek. Thompson, girdiği ağır polemiklerin katkısıyla aşağıdan tarihyazımının kurucu figürü gibi görünebilir, ancak Homo Academicus'u hatırlarsanız ve özellikle Bourdieu'nün LéviStrauss'a özel önem atfettiği diyagramını, E.P. Thompson burada hem az etkili hem de yerleşik akademik alanda pek az otorite taşıması itibariyle ancak ölümünden sonra ortaya çıan bir yarı-alanın timsali olabildi.

E.P. Thompson ismini Bourdieu'yle ilintili olarak boş yere anmıyorum, çünkü Fransız entelektüel alanının en ağır eleştirisini yaptı̆̆ The Poverty of Theory: An Orrery of Errors'ta [Kuramin Sefaleti: Bir Hatalar Dönencesi] (Thompson, [1978]1995), Bourdieu hakkında yazılabilecek en parlak yorumu herkesten çok daha evvel yapmıştı:

Bu ülkede [Britanya'da] sair "Batı Marksizmi" ithalat mümessillerinin (maalesef yıllar önce böylesi bir ithalat mümessilinin [New Left Review] kuruluşunda katkım olmuştu) gürültüsünden bunalan ve Fransa'da sosyoloji, iletişim ve eğitim kuramları, vs. ile ilgili en iyi Marksist geleneğin bu olduğunu zannedenlerden istirham ederim. Yeniden eğitimlerine Pierre Bourdieu okuyarak başlayabilirler (Thompson, 1995, s. 235).

Thompson için ifade ettiğimizin bir benzerini Henri Lefebvre için de söyleyebileceğimizi yukarıda açıklamıştım. Neil Smith ise polemikçiliğiyle meşhur ve David Harvey'le beraber 1980'lerden 2000'lerin başına kadar Marksist kent çalışmalarının en parlak alan kurucularından. Ne var ki, polemiğin belirli bir kurucu etkisi var ve kritik bir eşikten sonra asidin kendi kabına zarar vermesi gibi içinde bulunduğu figürün etkisini de kısıtlayabiliyor.

Bourdieu, David Harvey misali bir etkiye sahip oldu. Düşük düzeyde polemikle, bir hayli üretken olmak ve en az kendisi kadar üretken varislere sahip olmakla mümkün bir etkiden bahsediyorum. Bu nedenle, Jacques Ranciére'le giriştiği çoğunluğu tek taraflı polemik dışında Bourdieu'nün kendini içinde bulduğu alan çizgileri çekme mücadelesi, bir hegemonik belirlenim kavgası olmadı. Ranciére, neredeyse tamamını sadece Bourdieu'ye -onun açık ve örtük eleştirilerine adadığı- yönelttiği iki kitap yazdı, Filozof ve Yoksullarn ve Cahil Hoca (Ranciére, 2009; Ranciére, 2014). Ranciére'in belki acımasız bir gözükaralıkla kendine Bourdieu'nün putkırıcılığını atfet- 
mesinden kaynaklanan kitapların ilkinde, kitabın yarısı bir müphem sosyolog figürü olarak Bourdieu'yle konuşurken, Cahil Hoca, Bourdieu'nün cahilliğe vurgu yaptığı hemen hemen tek bir metne ve 1980'ler boyunca yazdığ 1 hemen her şeye bir cevap niteliği taşıyordu (Bourdieu, 1989). Bu polemiğin ayrıntılarına burada girmeye imkânımız yok.

Ancak, şunu söyleyebiliriz, Bourdieu, kendi kurduğu (Wacquant, 1989) Actes de la Recherche en Sciences Sociales ile programatik metinlerini yayınladı, Loic Wacquant ile birlikte de Anglofon dünyaya bu metinlerin aksettirilmesi fırsatına kavuştu. 1980'lerin başında çok daha faaldi, yapitları çok daha canlıydı, ama en azından Anglofon dünyada bu metinlerin kabulü 2000'lerin başına kadar gerçekleşmedi. Sosyoloji alanında tüketim ve orta sınıflarla ilgili metinlerde 1990'ların başında, fakat kent sosyolojisi içinde ancak 2000 'in ilk on yılının sonunda alanı tanımlayıcı bir kudrete erişti. Ölümünden sonra Bourdieu'nün yapıtı, 2010'ların başı itibariyle hem Richard Swedberg gibi ekonomi sosyolojisinin önemli figürlerinin ilgisine mazhar oldu, hem de Mike Savage gibi eleştirel sosyologların alan hakkındaki revizyonlarının ayrılmaz bir parçası haline geldi (Savage, 2012; Swedberg, 2011). Bu yazının son kısmında, münhasıran kent sosyolojisi alanında, Wacquant ve Bourdieu'nün mekâna dair programatik metinlerine göz atacağız.

\section{Bourdieu'nün Mekâna Dair Programı}

Tim Cresswell, Society and Space'te, Bourdieu'nün ölümünün ardından yazdığı anma yazısında onunla tanışıklıklarını aktarır. La distinction'ı Wisconsin, Madison'da yaptığ 1 doktora esnasında edinen Cresswell, David Stark'ın bir seminerinde Bourdieu okumaları yaptıkların ve dersin sonunda Bourdieu'nün kendisiyle tanışma ve onu sorgulama firsatı bulduklarını belirtir:

Bourdieu bizim saygılı ama neye işaret ettiği belirgin sorularımıza hoşgörüyle yaklaşt ancak kategorize edilmeyi reddetti, ne saf bir fenomenologdu ne de gizli bir Marksist. Marx'ın solunda olduğu konusunda ısrarcıydı... "gerçeklik belirsizdir, bizim işimizin gereği de onu daha belirsiz kılmaktır" iddiasında ısrarcı olduğu gibi (Cresswell, 2002, s. 379).

Cresswell, Bourdieu'nün mekân kavramının Lefebvreci mekân kavramıyla hiçbir ilgisi olmadığının altını çizdikten sonra ekler, "Bourdieu'nün toplumsal mekân [kavramı] insanların, nesnelerin, zevklerin ve eğilimlerin iki-boyutlu kavramsal düzenlenişidir." (Cresswell, 2002, s. 380) 
Tabii Bourdieu, kendi kurduğu dergide yayınladığı makalelerinde veya 1980'lerdeki alan kurucu makalelerini yayınladığı dönemde bir doktora dersindeki kadar çekingen veya sarkastik değildir. Social Space and Symbolic Power'da [Toplumsal Mekân ve Sembolik İktidar] sosyolojik yaklaşımını konstrüktivist yapısalcılık veya yapısalcı konstrüktivist biçiminde tarif eder ve ona göre yapısalcilık,

Saussurecü veya Lévi-Straussçu gelenekten farklı olarak sosyal dünyanın içinde ve sadece sembolik sistemlerle (dil, mitler, vs.) kısıtlı olmamakla birlikte faillerinin bilinç ve iradelerinden bağımsız ve onların pratiklerini veya yorumlarını yönlendirme ve kısıtlama kabiliyetini hâiz objektif yapıların var olduğu anlamina gelir (Bourdieu, 1989, s. 14).

Konstrüktivizm ise toplumsal olanın iki türlü neşet etmesi veya doğuşu anlamına gelir. Burada Loic Wacquant'ın Fransızca'dan İngilizce'ye çevirisinde şu sorun mevcuttur: genesis, İngilizce'de içinde dinî göndermeleri de hâlâ taşıyan bir kavramdır, yaratılış anlamına da gelir, oysa, Fransızca genése, İngilizcedeki "origin" kavramıyla da pekâlâ karşılanabilir. Bourdieu'nün diğer metinlerini de göz önüne alırsak, "genesis"ten ziyade "origin" den bahsettiği, neşet edendense bir başlangıçtan, bir oluşma anından, bir doğuştan bahsettiğini addedebiliriz.

Konstrüktivizm bu doğuşun iki türlü hâliyle ilintilidir: "bir yanda alg1lama, düşünce ve eylem şemalarıyla ilgilidir, ki bunlar benim habitus dediğim şeyin kurucusudur, ve diğer yandan, toplumsal yapılar, gündelik hayatta ise toplumsal sınıflar diye adlandırdığımız ama benim özellikle alanlar ve gruplar dediğim [şeyle] (Bourdieu, 1989, s. 14)."

1980'lerde Outline of a Theory of Practice'ten sonra (Bourdieu, 1977) kuramsal açıdan en çarpıcı makalelerini yazan Bourdieu'nün hedefinde toplumsal sınıfların gerçeklikte alanlar ve grupların çalışılmasıyla ikame edilmesi vardır. Bu açıdan, bu dönemde yayınlanan Bourdieu'nün bir seri makalesi, Marksist sınıf kuramıla kopuşla ilintilidir. Social Space and Symbolic Power [Toplumsal Mekân ve Sembolik İktidar] Bourdieu'nün daha sonra İngilizce'de yayınlanan nispeten geç dönem yazılarının derlemesinin de kısmi başlığını oluşturacaktır (Bourdieu \& Thompson, 1991). Aynı şekilde, Social Space and the Genesis of Groups makalesi de hem bir yll içinde iki farklı İngilizce akademik dergide, çok ufak farklılıklar ve dizgi değişiklikleriyle çeviriyle ilintilidir bu farklılıklar, mesela, "impregnated" [gebeyiz] gibi arkaik ve seksist bir kavramın, "imbued" [içselleştirmişiz] ile yer değiştirmesiyle- yayınlandı (Bourdieu, 1985a, 1985b). 
Makalelerin neşet ettiği, yani doğduğu yer, 1984 yılında, Polonya'da Solidarnosc'un yükseldiği, Fransa'da FKP'nin çökmeye başladığı, reel sosyalizmin perestroyka ve glasnostu daha seslendirmek üzere olduğu kritik bir zamanda yayınlanan, sosyolojinin toplumsal siniflar denilen mefhumdan kurtulmasına çağıracak olan Espace social et genese des "classes" [Toplumsal mekân ve "sınıfların" doğuşu] yazısıydı (Bourdieu, 1984). 2018 başında IJURR'da yayınlanan makale de, bu üç metnin bir varyasyonundan başka bir şey değildir. Lâkin, ilgi çekici bir durum var, Bourdieu'nün yazısı, Frankofon akademide bir patlama imkânı sağlamak için yazılmıştı. Yazının açılış cümlesi, "toplumsal mekân kuramının inşası Marksist kuramla bir dizi kopuş gerektirmektedir" idi (Bourdieu, 1984, s. 3).

Bu makalenin Fransızcasıyla İngilizcesi arasında çok ciddi bir fark mevcuttur: ilkinde sinıflar tırnak içerisinde başlıkta geçerken, ikincisi -ve aslında üçüncüsünde- sınıflara vurgu yerini toplumsal gruplara bırakmıştı (Bourdieu, 1984, 1985b, 1985a). Bunun hangi sebeple yapıldığını bilmemize imkân yok. Ancak metnin içeriğini göz önüne alırsak ve Bourdieu'nün toplumsal sınıfları bir sosyolojik nesne olarak aşma çabası ve toplumsal mekân içerisinde konumlandırma yönünde bir irade taşıdığını düşünürsek, Fransızca baskının başlığında "sınıflar"ın tırnak içine alınmasını anlamlandırabiliriz. Öte yandan, İngilizcede bu vurgunun yapılmamış olması, Bourdieu'nün Anglofon sosyolojiye görece yeni müdahalesiyle ve yerleşik eyleme biçimlerinin, doksanın icrasında 1980'lerde hâlâ etkin olan Marksizm ve sınıf kavramlarını ötelemek amacı taşıyabilir yönünde salt spekülatif -ve Bourdieu'nün Homo Academicus'undan mülhem- bir varsayımda bulunabiliriz. Cevabın kolayca veremeyeceğimiz soru şu, acaba doksadaki Bourdieu'yle epistemik Bourdieu burada mı ayrışmaya başlamıştı?

Yazıda, IJURR yazısında göreceğimiz sosyolojinin revizyonu -ya da yeniden inşasi- yönünden bir başlangiç salvosu var: "sosyoloji kendini toplumsal topoloji olarak sunar...Failler ve fail grupları [toplumsal dünyanın bir mekân olarak temsili içinde] göreli konumlarına göre tanımlanırlar. (Bourdieu, 1985a, ss. 723-724)" Toplumsal alan böylelikle çok-boyutlu bir konumlanmalar mekânıdır ve failler bu mekânda dağıtılmıştır.

"Kağıt üzerinde sinıflar" diye ekler Bourdieu "ancak kuramlara ait $k u$ ramsal bir varlığa sahiptir (Bourdieu, 1985a, s. 725)." Zoologların ya da botanistlerin sınıflandırmasına benzer bir kavramdır sınıf; fiilen bir sınıf değildir, ancak mücadele için harekete geçmiş bir gruptan bahsedebiliriz ve burada da beliren "en fazla muhtemel bir simf' tır (Bourdieu, 1985a, s. 725). Kavramları şeyleştirmenin [reification], ya da algılanabilir realizmin aksine, Bourdieu 
sınıfların salt mekânda ayırt edilebileceğini, gerçek gruplar olarak var olmadıklarını, ancak bireylerin kendilerini pratikte mevcut gruplar olarak ailelerde, kulüplerde, derneklerde ve hattâ sendika veya toplumsal hareketlerde kurabileceklerini iddia eder (Bourdieu, 1985a, s. 725). Bu iddiası, Marksist gelenekle ilk kopuş noktasıdır, Marksizm ya inşa edilmiş sınıfla gerçek sınıfı bir ve aynı zanneder, ya da bu ayrımı yapabilse bile "kendindesınıf"la "kendi-için-sınıf" ayrımına giderek "[sınıf] bilincini uyandırma"yı Parti'nin aydınlanmış önderliğine atfeder. Her hâlükârda diye ekler Bourdieu, "mücadele içindeki bir grup"un objektif ekonomik koşullardan nasıl doğduğunun koşulları ve oluşumu açıklanmadan bırakılmıştır (Bourdieu, 1985a, ss. 726-727).

Bourdieu'nün buradaki önerisi Erving Goffman'ı takip ederek kişinin "yer"ini bilerek konumlandığını ayırt etmektir. Marksist "sınıf bilinci"nin esasında sınıf bilinçdışı vardır ve bu bilinçdışının tekâbül ettiği durum erişilmiş bir konum bilincidir (Bourdieu, 1985a, s. 728). Bu yerini bilme hâli, bir kategoriye ait olmaktır ve iktidar tarafından çağırılmaktır. Kategoresthai fiili der, bize hem kategorileri işaret eder, hem de kamusal olarak itham etmek anlamını taşır (Bourdieu, 1985a, s. 729). Geleneksel Kabylia'da kategorize etmek, adlandırmak, ozanların görevidir ve ozanlar, kriz durumlarında dünyanın anlamı kayıp gitmeye başladığında- savaş lordları ve elçiler gibi temel siyasi işlevler üstlenmeye başlarlar (Bourdieu, 1985a, s. 729). Toplumsal dünyayla göreli özerklik alanlarının ayrışmasıyla beraber, anlam üretme ve empoze etmek görevi kültürel üretim alanına doğru yönelir. Böylelikle toplumsal dünyanın nesneleşmiş temsillerini üreten profesyonel üreticiler ortaya çıkar (Bourdieu, 1985a, s. 730).

Toplumsal dünyanın deneyimleri farklı ifadelerle yansitılır. Bu nedenle, toplumsal Gestalten [Bütünlük] objektif olarak varolur. Burada birbirine benzer özellikler taşıyan failler, toplumsal gölgeler, mahalleler, mekânsal segregasyona maruz kalmış yerler, Weber'in Stände'si gibi ortak özelliklere sahiptir. Toplumsal mekân ve oradan doğan spontane farklılıklar, Stände ya da yaşam biçimleri mekânı gibi bir işlev görür. Ayrım, distinction, toplumsal mekânın bizâtihi kendi yapısında yazılmış farklılıktır -tabii, o farklılıklar yapının kendisine ait kategoriler üzerinden algılanır. "Ayrım"ın sadece başka bir adlandırılışı olan sembolik sermaye -ayrımla müsemmadır- algılar üzerinden oluşur. Weberci Stand bu toplumsal mekânun bölümlenmesinden başka bir şey değildir (Bourdieu, 1985a, ss. 730-731).

Sembolik sermayenin özellikle bilimin içerisinde nasıl kurulduğunu, nominal olanın nasıl gerçek olan anlamına geldiğini izâh ettikten sonra, 
Bourdieu bir kere daha Marksist sınıf kuramına, kuramın yetersizliğine geri döner. Marksist sınıf kuramı toplumsal dünyayı sadece ekonomik alanla açıklamaya çalıştığı için farklı alanları ve alt-alanları göz ardı etmiştir. Özellikle kültür üretimi alanındaki ilişkilere önem vermemiştir. Bu nedenle Marksist kuram tek-boyutlu bir toplumsal dünya kurmuş, tanımlarını iki bloğun zıtlı̆̆ üzerine geliştirdiği için de "emekçi aristokrasisi," "işçi sınıfinın burjuvalaşması," gibi bloklar arası sınırlara dair tartışmalarda takılıp kalmıştır. Bourdieu, gerçekte toplumsal mekânın çok-boyutlu bir mekân olduğunu, bu açık alan kümelerinin göreli özerk olduğunu, ancak aşağ1 yukarı doğrudan ya da güçlü bir biçimde ekonomik üretim alanının diğer alanların işlevleri ve dönüşümlerinde mütehakkim olduğunu belirtir (Bourdieu, 1985a, s. 736). Devlet iktidarının burada isimlendirici -takdis edici- ve şekillendirici bir rolü vardır.

Bir sinuf sadece -ama sadece diye iki kere vurgular Bourdieu- kendi adına konuşabilecek bir temsil figürü bulduğunda varolabilir. Bourdieu için "Parti'nin işçi sınıfı" ya da "İşçi sınıfının Parti" olmasıyla "Kilisenin Papa" veya "Papa'nın Kilise" olması gibi kanonlaşmış ifadelerin birbirlerinden farkı yoktur. Sınıf büyülü bir gerçeklik, "mistik bir gövde"dir. Sınıf kuramı tarih içinde Marks'tan başlayarak kurulmuş muazzam kuramsal ve pratik bir icattır. Ancak, sınıfın varlığ 1 yetkilendirilmiş temsilcilerle mümkündür ve sadece bu sayede "kağıt üzerindeki sınıf" muhtemel bir sinıf-grup olarak ortaya çıkar. Sorun da buradadır, Marksist kuram, muhtemelen ilk bilimsel toplum kuramı olmasına rağmen, bir paradoksun kurbanıdır. Geçmişte kuram etkisi en güçlü hissedilen Marksizmin kendisi bugün toplumsal dünyaya dair yeterli kuramsal gelişimin önündeki en büyük engeldir (Bourdieu, 1985a, ss. 735-742).

Bourdieu'nün Marksizme dair yorumları çok ağırdır ve 1990'ların sonunda iddialarının en azından bir kısmından örtük olarak çark edecektir (Bourdieu, 1998). Metnin koyu polemik tonu, muhtemelen Bourdieu'nün 1980'lerde akademik sosyolojinin hâlâ en eleştirel alanı olan ve Marksist etkiyi canlı bir biçimde taşıyan kent sosyolojisinde kabul görmemesinin başlıca sebebidir. Metin, toplumsal mekânla ilgili değildir. Marksist sınıf kuramının yerine Bourdieucü bir "toplumsal grup" kuramı ikame etmeye çalışır ve sınıfın yerini gruplara terk etmesi, sosyolojinin sınıfların değil, mekânsal bir topoloji çalışması hâline dönüşmesini kurucu bir program olarak önerir. En önemli sorunu, Marksist doksayı verili kabul etmesi, 1980'lerin başında ölü attan farkı kalmayan FKP'yi 1950'ler ve 1960'ların enternasyonelist iktidar makinesi gibi telakki etmesidir. Kanaatimce, Bour- 
dieu, Althusserciliğin ve onun Poulantzas varyantınn içinden Marksizmi aşmaya çalışmıştır. Ve her ne kadar çok haklı eleştiriler getirse bile, Marksizmi toplumsal dünyayı anlamanın önünde büyük engel addederek pire için yorganı yakmaya çalışmıştır.

Loic Wacquant'ın, IJURR'da 2018 başında Bourdieucü mekânsal programın ilânı özelliği taşıyan sayıda, yukarıda aktardığım Espace social et genese des "classes"ı değil de, çok daha minör bir konuşmayı seçmesi ilginç bir tercihtir. Özellikle konuşmada Bourdieu'nün okuru mekân hakkında daha ayrıntılı bir kavrayış için Espace social'e yönlendirdiği düşünülürse daha da ilgi çekici olur bu durum. Bourdieu'nün Marksizme karşı neredeyse kavga$\mathrm{Cl}$, temelde de müstehzi yaklaşımı -Papa'nın Kilise olmasıyla Parti'nin sınıf olmasının eşdeğerliğini hatırlayın- ihtimaldir ki Wacquant'ın tercihinde etkili olmuştur.

Wacquant'in seçtiği Social Space and the Genesis of Appropriated Physical Space [Toplumsal Mekân ve Temellük Edilmiş Fiziksel Mekânın Doğuşu/Oluşumu] (Bourdieu, 2018) yazısı da bir konuşmadan aktarılmış ve tercüme edilmiştir. Tabii, burada ilk defa fiziksel mekânı tanımlama uğraşına yönelir Bourdieu: "insan varlığı aynı anda hem biyolojik varlık hem de toplumsal fail"dir ve bu ikisinin birlikteliği toplumsal mekânla, hatta daha doğrusu diyerek ekler, alanlarla ilişkileri içinde ve dolayımıyla oluşur (Bourdieu, 2018, s. 106). Burada bir defa daha toplumsal olguyu locus ve topos üzerinden açıklar, göreli ve ilişkisel konumlarla çalışmaya çağrıda bulunur ve sosyolojinin bir sosyal topoloji olduğu yönünde yeni bir heterodoksiye davet eder (Bourdieu, 2018, s. 106).

Bourdieu, mekânın eylemsizliğini vurgular, Leibniz'den başlayarak şeyleşmiş toplumsal mekânın, ya da temellük edilmiş mekânın, failler ve özellikleri arasındaki belirli bir ilişkiden kurulduğunu ifade eder (Bourdieu, 2018, s. 107). Toplumsal mekân fiziksel mekâna yazılmış olduğundan ötürü, yer değiştirmek zordur, bu nedenle eylemsiz veya durağan [inert] bir yap1dır diye ekler. Bourdieu, Paris'te Seine'in Sağ ve Sol kıyıları arasındaki ayrımın bu eylemsizliğin ekonomik ve kültürel iktidarın nasıl timsali olduğuna işaret eder.

Burada beliren sorun şu ki, kentsel mekân hakkında 1960'lardan bu yana yazılıp çizilenlerin hemen hepsi, mekânın eylemsiz olmadığına işaret eder, onun edilgen bir Öklidyen düzlem değil, eyleme kabiliyetini hâiz, değiştirme kudretine sahip, sabit olan tek gerçekliği hareketliliği olan bir özne yap1cl olduğundan bahseder. Mekân bir özne değildir ama özne üretir. Yaratıcı yıkımdan, mekânın tarihsel-coğrafi diyalektiğine, üçüncü mekândan, ser- 
mayenin üçüncü (veya, Lefebvre'e göre ikinci) döngüsüne değin fiziksel mekân eylemsiz değildir, mütemadiyen hareket hâlindedir (Dear \& Scott, 1981; Harvey, 1982; Lefebvre, 1991; Soja, 1980).

Bourdieu için ise mekân zihinsel bir yapıdır. Mekânın zihinsel bir kategori olduğu iddiası Bourdieu'ye özgü bir iddia değil, bunun toplumsal mekâna dönüşümü ise Levi-Strauss' un araştırmalarında öne çıan düalistik bir mekân kurgusunun ürünü (Lévi-Strauss, 1955, ss. 254-257). Lévi-Strauss mekânın zihinsel bir yapı olduğunu, 1955'te yayınlanan otobiyografik metni Tristes Tropiques'te Bororo'lardan bahsettiği kısımda ele aldı. Burada bir Bororo köyünün nasıl hem fiziksel, hem de zihinsel yapılar itibariyle ikiye bölündügünü izâh etti. Bu açıdan, Bourdieu'nün 1960'larda Kabyle evinde yaptığı, Levi-Strauss'un 1940'larda bir Amazon köyünde yaptı̆̆ıyla mukayese edilebilir (Bourdieu, 1970). Bourdieucü mekân, mekânın fiziksel gerçekliği, şeyleşmiş toplumsal mekândan başka bir şey değildir (Bourdieu, 2018, s. 108). Mekân, temellük edildiğinde, fizikselleştiğinde, iktidarın nesnesi olur, "mimari mekânların sessiz etkisi doğrudan bedeni hedef alır (Bourdieu, 2018, s. 108)."

Bourdieu'ye göre toplumsal mekân soyut bir mekândır ve bir dizi altalandan veya alandan oluşur. Ekonomik, entelektüel, sanatsal, akademik ve bürokratik alanlar bunlardan bazılarıdır. Nesneleşmiş veya fiziksel gerçeklik kazanmış toplumsal mekân, fiziksel mekân içinde farklı ürünlerin ve hizmetlerin bölüşümü demek olduğu kadar farklı bireysel faillerin ve grupların da yerleştiği mekân anlamını kazanır. Toplumsal mekânın bu ikili yapısı içinde fiziksel mekân gerçekleşir: hem ürünlerin ve hizmetlerin, hem de faillerin yerleştiği mekândır (Bourdieu, 2018, s. 109).

Bu program ilanında, bu Bourdieucü mekân manifestosu metninde, belki de en zorlayıcı ve daha önce ele aldığımız Espace Social metnini tamamlayıcı özellik, Bourdieu'nün mekânın kârı kavramını ortaya atmasıdır. Bu kavram, Marksist ekonomi-politik eleştirinin belki bir asırlık çaba sonucunda mekânın rant sağladığı, kârla ilişkisi olmadığı zımnî kabulünü yıkıp geçen bir baş aşağı döndürme, bir alt üst etme denemesidir. Bourdieu farkl1lık rantından, tekelci ranttan, rantla artı-değerin uzlaşısı ve mücadelesinden, rantiyer sınıf kesimleriyle artı-değeri temellük eden kesimlerin antagonizma ve uzlaşısından, finans sermayesinin hem arabuluculuk hem de bir sonraki döngüye aktarllacak tarihsel-coğrafi makas değiştirici rolünden bahsetmez. Bourdieu için toplumsal mücadelelerin nesneleşmiş biçimi mekânın kârıdır (Bourdieu, 2018, s. 110). 
Bourdieu, mekânın kârını üç ayrı sınıfta değerlendirir, birincisi belirli kurumlar ve yerlere yakın olmaktan kaynaklanan durumsal rant, ikincisi, hiyerarşik konum veya mertebeden kaynaklanan kâr, üçüncüsü ise belirli bir yerde bulunmanın, mekânı işgâl etmenin kârıdır: geniş parklar, apartmanlar, çim peyzaj, vs. İkinci kâr, doğrudan sembolik iktidarla ilintiliyken, üçüncü mekânsal kâr fiziksel mekân üzerindeki iktidar olarak nitelendirilebilir (Bourdieu, 2018, s. 111). Bourdieu, bütün bu kâr biçimlerinin tasvirinin sonunda, habitus'ün habitat yarattı̆ını, bunu da toplumsal kullanımlar aracılığıyla gerçekleştirdiği savını öne sürer (Bourdieu, 2018, s. 111). Dikkatli bir göz, Bourdieu'nün mekânın kârları tespitinde adlandırdığı üç kâr biçiminde doğrudan Marx'ın Kapital'in üçüncü cildinde öne sürdüğü üç rant biçiminin -farklılık rantı I, II ve mutlak rant- belirgin bir etkisi olduğunu ayırt edebilir (Marx, 1993, s. 779-907). Ne var ki, Bourdieu'nün jesti Marx'ın kuramını doksa düzleminde yeniden inşa etmek değil, onun ortodoksisini kırmak üzerinde temellenmiştir.

\section{Bourdieu'nün "Kayıp Kent Sosyolojisi”}

Bourdieu'nün kentsel kurama tam anlamıla temellük edilmesi, Bourdieucü toplumsal mekân anlayışının eleştirel kentsel düşünce üzerinden yeniden yorumlanması, yukarıda saydığımız kırılma noktalarının dışında, Mike Savage tarafından 2012 yılında açıkça ifade edilir. Savage, kent çalışmalarının bir çıkmazda olduğunu, popüler kuramsal çerçevelerle olgusal çalışmalar arasındaki uzaklığın giderek arttığını belirtir (Savage, 2012, s. 511). Bu çıkmazın çözümü için kentsel kuramın Bourdieu'nün alan, habitus ve farklı sermaye biçimlerine dair çözümlemeleriyle desteklenmesi gerekmektedir, Bourdieu'nün "kayıp kent sosyolojisi” ortaya çkarılmalıdır (Savage, 2012, s. 512). Her ne kadar, Bourdieu'yü kent sosyolojisine çağırırken Savage, güzergâhı da, istikameti de şaşırıp, yeni kent çalışmalarının Deleuze ve Guattari'den, bilhassa onların deterritorialization/reterritorialization ikilisinden çok şey kazanabileceğini savunsa da, esas önerisi Bourdieu'nün alan analizinin ilişkisellik bağlamında Lefebvre'ci tarihselciliğin sorunlarını çözeceği ve eskpresif bütünlük anlayışının zayıflı̆̆ını ortadan kaldıracağı yönündedir (Savage, 2012, s. 517).

Sorun, Lefebvre'den ekspresif bütünlük kavramın, tarihselciliğin kentsel mekâna dair yorumunu çıkardığımız zaman Lefebvreci bir kuram kalmayacağ1 sorunudur. Bütünlüğün mekâna dair en önemli eleştirel zemini teşkil ettiğini başka yerde izâh etmeye çalıştım (Gülhan, 2013). Ancak, ekspresif bütünlüğe dair eleştiriye yanıtı şöyle özetleyebilirim, düşünce düzleminde 
tek bir bütünlük kavrayışı mevcut değildir. Marksist toplumsal dünyayı kuramsallaştırma ve -tabii ki- değiştirme programının ayrılmaz bir parçasıdır bütünlük arayışı, zerrede dünyanın derdini görme çabasıdır. Bundan feragat edildiğinde, geriye kompartmanlara bölünmüş, kategorize edilmiş bir değişken serileri silsilesi kalmaması imkânı da mevcut değildir. Loic Wacquant, varislerin en önemlisi olarak bütünlük sorununun en az Bourdieu kadar farkındadır.

Wacquant, Bourdieu'nün şehre bir kovboy gibi girdiği program manifestosunu üç hareketle özetler: Bourdieu'nün kentleşme ve tahakkümün mekânsal boyutuyla ilgili olgusal ilgisini su yüzüne çıkarmak, ikincisi, topolojik akıl yürütmenin ve sembolik, toplumsal, fiziksel mekân triyalektiğinin Bourdieu'nün toplum ve tarih görüşünün merkezinde olduğunu açılamak, ve son olarak, Bourdieu'nün araştırma ve kuramsal ilkelerini uygulamakta olan yeni kuşak akademisyenlerin çalışmalarını vurgulamak (Wacquant, 2018, s. 91).

Wacquant, her hegemonik kurucu gibi neşet noktasına giderek başlar, Louis Wirth'ün 1938 yılında yayınladığı "bir yaşam biçimi olarak şehircilik"i Bourdieu'de "şehri olmayan kentliler" de izini sürerek onun erken döneminde yaşadığı kasabadaki kentleşme sancılarını arar(Wacquant, 2018, s. 93-95). Ne var ki, aradığı hegemonik noktada ne Wirth ne de Chicago okulu meskundur artık. Daha sonra, Fransa'nın taşrasından Cezayir'e gider, Bourdieu'nün Savage'dan mülhem kayıp kent sosyolojisini şehirdeki toplumsal yapı ve deneyimler üzerine gözlemlerinde arar (Wacquant, 2018, s. 97). $\mathrm{Bu}$ arayışlarda, bir kere daha yeni kent sosyolojisine ve Henri Lefebvre'in Manuel Castells tarafından eleştirisinde -ya da, herhangi bir Marksist polemikte- aşina olduğumuz, uyarı karşımıza çıkar: "Fransız sosyolog [Bourdieu] mekânın fetişleştirilmesine karşı [bizi] ikaz eder ve soyut bir düzlemde toplumsal mekânla fiziksel mekân arasındaki ilişkileri" Fransa'nın taşrasında ve Cezayir araştırmalarında formüle etmiştir (Wacquant, 2018, s. 97). Mekân, zamandan sonra belki, fetişleştirmeye en teşne meseledir.

Dört durak noktasından bahseder Loic Wacquant: ilki Bachelardcı duraktır, verili analiz kategorilerinin reddedildiği yerdir burası. İkinci durak noktası Webercidir, fail, dünya ve analistin bizâtihi kendisinin üçlü tarihselleştirilmesi buradan doğacaktır, bu sayede habitus kavramının, toplumsal mekân kavramının ve epistemik düşünümselliğin devreye girmesi mümkün olacaktır. Üçüncü durak noktası Leibnizci-Durkheimcidir. Bu noktada müşterek ve çoklu mütekabiliyetlerin sembolik mekân, toplumsal mekân ve fiziksel mekân içinde topolojik yaklaşımına ve okunmasına fırsat verilecek- 
tir. Son durak noktası ise Cassirerci durak noktasıdır, burada sembolik yapıların kurucu etkinliğini tanımak ve öznelliği nasıl oluşturduğunu anlamak mümkündür; yani habitusun ve nesnel konumlanmaların üzerinden kurumların nasıl kurulduğunu kavrayabilmek (Wacquant, 2018, s. 98-99).

Bu dört durak noktasından hareket eder Wacquant ve Bourdieu'den öğrenebileceğimiz üç meseleye işaret eder. Öncelikle, kavramları fetişleştirmekten kaçınılmalıdır. Zira, Bourdieu sıklıkla bir "kuramcı" olarak aksettirilse de, bizzat kendisi "gösterişçi kuramsallaştırmadan" hazzetmez. İkinci uyarısı ilkiyle ilişkilidir, Bourdieu'nün kavramlarını kullanan sınırsız sayıda yazar Bourdieu'nün renklerine bürünseler de onun kavramsal kümesi esasında akademisyenlerin analizlerinde gerçek bir rol oynamaz. Üçüncüsü, Bourdieu'nün kavramları birbirinden ayrılabilir, tabiri caizse bölünmez bir bütün değildir bu kavram kümeleri. Habitus'tan bahsederken alandan konuşmayabilir Bourdieu; bu nedenle Wacquant'ın tavsiyesi bir yığın kavramla uğraşıp onların hiçbirinin hakkını verememektense, kısıtlı bir kavram kümesini yeterli analitik çerçevede uygulamak yönündedir (Wacquant, 2018, s. 100).

\section{Sonuç}

Tavsiyeler bir alanda yeni bir program kurabilir, hattâ yeni bir doksanın kurulmasına giden yolu açabilir. Wacquant'ın aktardığım müdahalesi, temelde yukarıda IJURR'da Bourdieu'nün alıntılanmasına dair rakamlarla göstermeye çalıştığım gibi, Bourdieu'nün rolünün artık kent sosyolojisi ve kent çalışmaları alanında kurulmasından sonra geldi. Buna perçinleyici hamle diyebiliriz. Perçinleyici hamle, alanın Bourdieucülügü temellük etmesine dair düzeltici uyarılar da taşımaktadır. Bu perçinleyici ve düzeltici uyarıların her birini Wacquant belirtik kılmıştır. Fakat, Bourdieu'nün alana müdahalesinin nesneleştirmesini, daha doğrusu nesneleştireni nesneleştirme hamlesini yapmaktan geri durmuştur.

Bourdieu'nün kanımca en muazzam meta-kuramsal ve olgusal metni, Outlines of a Theory of Practice'te işaret ettiği gibi, doksa, işlerin doğal düzenini, kurulu sistemi, içinde yanılmaları ve sıradanlıkları da barındırdığı için, belki de dışı olmayan bir yeri işaret ettiği için, ortodoksi veya heterodoksiden farklıdır (Bourdieu, 1977, ss. 160-165). Muhtemelen sorun burada başl1yor, alanın -yeni kent sosyolojisinin- doksası var miydı? Akademik eyleme biçimlerini düşünürsek, düşünsel üretim faaliyetinin dışarıdan bütün hareketliliğine rağmen içeriden eylemsizliğini göz önüne alırsak -homo academi- 
cus'u hatırlayarak- belirli bir zaman diliminde belirli bir doksanın hâkim olduğunu söyleyebiliriz. Ne var ki, bu doksa, tabii gözlemlenebilir olmaktan uzak, ortodoksinin -Chicago Okulu'nun kalıntılarına, nicel ve yapısal işlevselciliğin hakimiyetine karşı tepkisel- ve heterodoksinin -Castells'in yapısalcllık tınılı pozitivizmine karşı, Hegelcilikten, Heidegger'den, semiyolojiden beslenen bir Lefebvreciliği arkasına almış- iki zıt kutbu ve birbirine karışmış renkleri arasında hareket etti.

Her yeni kurulan sembolik düzen gibi, Bourdieucülügün alana nüfuzu kurulu kuramsal alet edevatı, nesneleştirme yöntemlerini, nesneyi tanımlama manevralarını ve o nesneyi aksettirme biçimlerini, kısaca verili ortodoksiyi sorgulayarak başladı. Verili ve mevcut doksanın eleştirisi, Bourdieucülük açısından nispeten kolaydı, zira, yeni kent sosyolojisinin çoğunu kendi kendine yaptığı meta-kuramsal bir hamleden sonra tutunacağ 1 bir omurga ya kalmamıştı ya da omurga 1980'lerin politik dönüşümlerinin baskısı altında hızla şekil değiştirmekteydi.

Gene Bourdieu'yü takip ederek diyebiliriz ki, doksanın gerçekliği ancak kanaat alanında negatif olarak, reddiye üzerinden gösterilebilir (Bourdieu, 1977, s. 168). Bourdieucülüğün yeni bir ortodoksi mi imal etmekte olduğu, yoksa heterodoksinin mevzilerini mi güçlendirdiği ancak senkronik olarak, zaman içerisinde gözlemleyebileceğimiz bir mesele. Fakat üç şeyi söyleyebiliriz, birincisi, Bourdieucü mekân, yani toplumsal mekân, ne Castells'in tanımladığ1 -önce kolektif tüketimden yola çıkan, kentsel olanın nesne olmasını sağlayan, sonra toplumsal hareketlerin akışkanlığına dayanan- mekân, ne de Lefebvre'in fiziksel olanın triyalektiğe dahil olduğu ve plancının, mimarın, bürokratın, sanatçının mukim olduğu mekân. Bourdieu'nün toplumsal mekânı her şeyden önce bir metafor.

İkincisi, doğrudan bu metafor olma hâliyle ilgili, kısmen Castells'in ama esas olarak Lefebvre'in ve Harvey'nin mekânsal muhayyilesi fiziksel olandan -tarihsel-coğrafi düzlemden- başlarken, Bourdieu yolu tersten kat ediyor ve sosyolojiyi toplumsal topolojiye büküyor. Failler arasındaki ilişki, farklı grupların sembolik tahayyülleri ve tabii tahayyül etmenin konumsallığı, herkesin bir metaforik düzlemde ve bunun sahihleştiği fiziksel düzlemdeki yeri -locus'u- bu yerlerin bölüşümünün ortaya çıkardığı topos, topos'un gözle görünür biçim aldığı habitus, o habitusun barındığı alanlar, altalanlar, grupların hareket hâlindeyken -sembolik iktidara karşı ya da onun içinde- ortaklaşa adlandırdığımız şeylere -sınıf, toplumsal cinsiyet, aidiyet, etnisite, vd.- dönüşmesi, fevkalade ilişkisel ve mümbit bir muhayyile sunuyor bize. Ne var ki, bu muhayyilenin ne kadar mekânsal olduğu ne kadar 
mekânı bir şeyler düzeninin metaforu olarak sunduğu sorusunda ikincisi, yani Bourdieucü mekânın sosyolojik bir metafor olduğu gerçeği, daha ağır basıyor. Mekân sosyolojiktir, kesinlikle evet, ama metaforik mekânın ne raddede sosyolojik olduğu başka bir tartışmanın konusudur.

Üçüncüsü, mekânın fizikselliğinin alan ya da alanlar açısından taşıdığı önemi içeriyor: yeni kent sosyolojisi ve onun ardılı veya çağdaşı bir dizi yaklaşım -postmodern şehircilik, postmodern mimari, küresel veya dünya kenti literatürü, heterodoks şehircilik ve mimari yaklaşımlar- belirli bir kentsel mekân tahayyülünde ortaklaştılar. Misalen, üçüncü mekân, sadece kent sosyologları için sarih bir anlam taşımıyor, aynı zamanda mimarlara, sanat tarihçilerine, şehirciliğin farklı veçheleriyle iştigal edenler için de alet edevat kümesinin kullanışlı bir parçasını oluşturuyor. Hattâ, sitüasyonizmi, metaların kendi hayatlarını, Benjaminci kentsel kuramı da işin içine katarsak, kültürel çalışmaların, mimarlı̆̆ın, şehirciliğin farklı alanlarının sosyologlardan çok daha yoğun biçimde bu phonemeleri kullandığını ayırt edebiliriz. Alanların kendi ayrımını oluşturduğu, bu ayrım üzerinden kendi sembolik hiyerarşisini oluşturduğu muhakkak. Ancak, 1960'lar sonrası epistemik kırılma bir yığın alanı bir araya getirdi. Benzer biçimde, Marksist şehir ve bölge plancılığının yeni kent sosyolojisiyle ortaklığı, bakışımı, kavramsal simetrisi gözden kaçırılmayacak kadar baskın ve önemli. Sembolik düzenin toplumsal mekânda kurulması, toplumsal topolojinin icadının bu karşılıklılı̆̆ı ne kadar sürdürebileceği ise şüphelidir.

Bourdieu'nün ve onun varislerinin hem kentsel kurama, hem de sosyolojiye en büyük, hattâ eşsiz katkısı, 1970'lerin sonunda bir yığın günahla yaftalanıp rafa kaldırılan, envaı çeşit eleştiriyle unutturulan yapısalcılığın en verimli, en parlak ve en zihin açıcı yönlerini güncel sosyal bilimsel alana taşıyabilmesidir. Sosyoloji, yapısalcılığın yıkımından en fazla zarar gören alan olduğu için hem Bourdieu'ye böylesi bir yakınlık duymakta haklıdır, hem de Bourdieu'nün sayesinde bir zamanlar vaadedilmiş potansiyelinin gerçekliğini olgusal ve toplumsal dünyada sınamayı bir kere daha deneyecektir. Velhasil, Wacquant'in alegorisini takip edecek olursak, Bourdieu'nün şehre gelmesi bir dünyalar çarpışıyor endişesiyle değil, hoş gelmiş ve safalar getirmiş sevinciyle karşılanmalıdır. 


\section{Extended Abstract}

\section{Social Space and the Genesis of a Reflexive Sociology: Bourdieu's Interventions in the Study of Space}

This paper focuses on the concept of "social space," a key concept developed by Pierre Bourdieu for advancing his sociological research program. In investigating the possible novel venues of sociological inquiry opened up by the intervention provided by Bourdieu's use of social space, this paper ventures into the archives of International Journal of Urban and Regional Research to understand how Bourdieu's work was reflected upon within the field of urban research in the last four decades. New urban sociology and Marxist urbanism's understanding and interpretation of space have changed significantly throughout the years. Yet, Bourdieu had a certain theory effect, and this has acted upon a steady stream of research, especially since the 2000s. IJURR had gone through what we can call a series of theoretical ruptures in the three decades. Hence, while investigating the Bourdieu's oeuvre three important moments are animated here: first, the inherent rupture of the 1960s as a reaction to the Chicago School and its quantitative inheritors are explicated. The second moment requires critical engagement with the new-born -or, still-birth- new urban sociology and how Manuel Castells' theoretical approach created a new doxa in the academic field. The 1970s and 1980s was a crucial point of transformation for the urbanists. In the third moment, I investigated how Bourdieu's analysis was appropriated in the symbolic space of the sociological and urban sociological field. Bourdieu's conceptual framework created a plethora of new approaches, however, their analytical relationship with both Bourdieu's sociological program and the hitherto prevalent spatial imagination is frequently questioned. Here, I suggested an objectification of the Bourdieu's theoretical and research work and tried to locate the breaks and continuities.

The aim here is to locate two processes: on the one hand, I elucidate how urban sociology as a field, as per Bourdieu's definition, was transformed, and, on the other hand, I explained how a content analysis of IJURR would 
help us understand the intrinsic tensions, ruptures, and movements of urban theory.

In the first moment explicated in this paper lies the theoretical foundations of the Chicago School and how as a paradigm it dominated research and theory in urban sociology until the 1960s. That moment requires extensive treatment, however, I raise two problems here. First is the resemblance of Aristotelian sité and Chicago School's urbanism. Second is especially concerned with how the theoretical premises of this particular school of thought actually developed its own negation.

Even though the first moment studied here begins with the Chicago School, it also necessarily involves a thorough refutation of this paradigm. In the mid-1960s, a plethora of disciplines within social sciences, from sociology to political economy, from political science to public administration, and from the neo-classical economics to architecture, had gone through a certain rupture in their conceptualization of urban space. The linchpin of this rupture was Manuel Castells.

The second moment here begins with that rupture and is directly related to how space is constructed inside the field of urbanism. At this point, the most relevant institutional representative of the field is academic journals. International Journal of Urban and Regional Research served as the beacon of a new mode of objectifying urban space. IJURR had functioned as the paragon of the new paradigm and its role in the field was concerned with how space was scientifically constructed and how a novel discourse was produced. Of course, Manuel Castells' work is definitive here and we should inquire how his critique of urban ideology played out in the confines of the new journal.

The third moment is interested in how Pierre Bourdieu's and his inheritor Loic Wacquant's work was received in the field spearheaded by IJURR. Here, I used IJURR's full-text archives since 1977 kept electronically by EBSCO's Sociology Source Ultimate database. The main problem is evident: Bourdieu's sociological thought and his contributions to social theory had already matured by the 1980s and his conceptualization of the "social space" was already a full-fledged Notion. Yet, IJURR's papers showed scant interest in Bourdieu's work. Throughout the 1990s and early 2000s, amidst all the richness of Bourdieu's theoretical appurtenances, papers published in IJURR showed only interest in "social capital". These years were also the time period when globalization literature was triumphant and Amartya Sen and World Bank inadvertently declared "social capital" as part of their de- 
velopment agenda. Bourdieu was never a part of this frenzy, and in the latter part of the 1990s heavily criticized neoliberalism and its newspeak.

Here, the main focus is on how Bourdieu defined and developed "social space" as a founding concept within sociology. Simultaneously of interest is how IJURR functioned as a reference in the changes taking place within new urban sociology and critical urban theory and to what extent Bourdieusian notions and his theoretical practice were appropriated in this era. That moment extends to IJURR's 2018 issue edited by Wacquant that heralded a new spatial imagination based on Bourdieusian program.

Without any doubt, the Bourdieusian concept of "social space" is an intervention in hitherto existing urban theory and urban sociology and the aim here is to locate how IJURR represented different means and methods for defining and determining ruptures and frames. As Bourdieu himself aptly pointed out one cannot avoid objectifying the objectifying subject. The critical subject has to be objectified for the sake of scientific endeavor. In this vein, there exists a mainstream fallacy that treats Bourdieu as Marxist. And this contributes heavily to the eschewing of Bourdieu's key intervention: abstracting "social space" as a field where social groups move and in return, they themselves are constructed symbolically. This intervention is ultimately related to Bourdieu's refusal to treat the social class as a concrete object and digs deeper to understand and convey how Bourdieu reflected upon the theoretical practice inherent in sociology as a spatial science, as social topology. Yet, his this approach is laden with problems in its treatment of the built environment and in its reconceptualizations of historicogeographical analysis.

This paper does not intend to develop a counter-intervention against Bourdieusian intervention. Bourdieu rightfully pointed out that polemical tone serves to augment one's position on the field. Here, I attempt to foreground the import of Bourdieu's "social space," without jettisoning his other concepts like habitus, multiple correspondence analysis, allodoxia, the mobility of social positions, meta-sociology and sociology of sociology. It is fertile to harken back to Bourdieu's argument that social classes themselves are not mere abstractions, but rather movements of social classes within the field of politics, economy, and symbolic space.

In sum, space according to Bourdieu is a metaphorical space. The "social space" as implicated by Bourdieu is a construct, as explained himself in his contrast between structural constructivism and constructivist structuralism. Herein lies the sociological space, a place where differences, variables, chi- 
square analyses, multiple correspondence analyses reside. The elements of discourse, phonemes according to Bourdieu, have found their expressions in various forms: in human ecology, in the study of habitats, in architectural and planning spaces, spaces of class distinction, Third World, global cities, thirdspaces. Yet, Bourdieu's contribution to urban sociology is immense and especially given the fact that neoliberalism had a devastating impact on research agenda on urbanism, his ideas still provide a refreshing novelty and carry still uncovered theoretical ground.

\section{Kaynakça/References}

Althusser, L. (1977). For Marx. London: N L B.

Althusser, L. (1997). Reading capital. London: Verso.

Berry, B. J. L., \& Wheeler, J. O. (2005). Urban geography in America, 1950-2000: Paradigms and personalities. Routledge.

Bourdieu, P. (1969). Intellectual field and creative project. Information (International Social Science Council), 8(2), 89-119.

Bourdieu, P. (1970). The Berber house or the world reversed. Information (International Social Science Council), 9(2), 151-170.

Bourdieu, P. (1977). Outline of a theory of practice. (Esquisse d'une théorie de la pratique). Transl. by Richard Nice. (Repr.). Cambridge University Press.

Bourdieu, P. (1984). Espace social et genèse des "classes". Actes de la Recherche en Sciences Sociales, 52(1), 3-14. https://doi.org/10.3406/arss.1984.3327

Bourdieu, P. (1985a). The social space and the genesis of groups. Theory and Society, 14(6), 723-744. https://doi.org/10.1007/BF00174048

Bourdieu, P. (1985b). The social space and the genesis of groups. Information (International Social Science Council), 24(2), 195-220. https://doi.org/10.1177/053901885024002001

Bourdieu, P. (1988). Homo academicus. Stanford, CA: Stanford University Press.

Bourdieu, P. (1989). Social Space and Symbolic Power. Sociological Theory, 7(1), 14-25. https://doi.org/10.2307/202060

Bourdieu, P. (1991). L'ordre des choses [Entretien avec deux jeunes gens du nord de la France]. Actes de la recherche en sciences sociales, 90(1), 7-19.

Bourdieu, P. (1998). Acts of resistance: Against the new myths of our time. Polity Press.

Bourdieu, P. (2018). Social space and the genesis of appropriated physical space. International Journal of Urban \& Regional Research, 42(1), 106-114. https://doi.org/10.1111/1468-2427.12534

Bourdieu, P., \& Thompson, J. B. (1991). Language and symbolic power: the economy of linguistic exchanges. Cambridge: Polity in association with Basil Blackwell. 
Bourdieu, P., \& Wacquant, L. (2001). Neoliberal newspeak: notes on the new planetary vulgate. Radical Philosophy, (105).

Brenner, N., Jessop, B., Jones, M., \& Macleod, G. (2008). State/Space: A reader. John Wiley \& Sons.

Bridge, G. (2001). Estate agents as interpreters of economic and cultural capital: The gentrification premium in the Sydney housing market. International Journal of Urban \& Regional Research, 25(1), 87-101.

Burgess, E. W. (2015). Şehrin büyümesi: Araştırmaya giriş. içinde Şehir: Kent ortamındaki insan davranışlarının araştırılması üzerine öneriler. Ankara: Heretik.

Carpenter, J., \& Lees, L. (1995). Gentrification in New York, London and Paris: An international comparison. International Journal of Urban $\mathcal{E}$ Regional Research, 19(2), 286-303. https://doi.org/10.1111/j.1468-2427.1995.tb00505.x

Castells, M. (1968). Y a-t-il une sociologie urbaine? Sociologie du travail, 10(1), 72-90. https://doi.org/10.3406/sotra.1968.1380

Castells, M. (1976a). Is there an urban sociology? Içinde C.G. Pickvance (der.) Urban Sociology: Critical Essays. London: Tavistock Publications.

Castells, M. (1976b). Theory and ideology in urban sociology. Içinde C.G. Pickvance (der.) Urban Sociology: Critical Essays. London: Tavistock.

Castells, M. (1977). The urban question : a Marxist approach. London: Edward Arnold.

Castells, M. (2006). Changer la Ville: A Rejoinder. International Journal of Urban and Regional Research, 30(1), 219-223. https://doi.org/doi:10.1111/j.14682427.2006.00654.x

Castree, N., \& Gregory, D. (2006). David Harvey: a critical reader. içinde Antipode book series. Geliş tarihi gönderen http://www.loc.gov/catdir/toc/ecip0513/2005013795.html

Cresswell, T. (2002). Bourdieu's geographies: In memorium. Environment and Planning D: Society and Space, 20(4), 379-382. https://doi.org/10.1068/d2004t

Crysler, C. G. (2003). Writing spaces: discourses of architecture, urbanism, and the built environment, 1960-2000. içinde The Architext series. Geliş tarihi gönderen http://www.loc.gov/catdir/enhancements/fy0701/2002153874-d.html

de Decker, P., Kesteloot, C., de Maesschalck, F., \& Vranken, J. (2005). Revitalizing the city in an anti-urban context: Extreme right and the rise of urban policies in flanders, Belgium. International Journal of Urban \& Regional Research, 29(1), 152171. https://doi.org/10.1111/j.1468-2427.2005.00576.x

Dear, M. J., \& Scott, A. J. (1981). Urbanization and urban planning in capitalist society. London; New York: Methuen.

Degen, M. (2003). Fighting for the Global Catwalk: Formalizing Public Life in Castlefield (Manchester) and Diluting Public Life in el Raval (Barcelona). International Journal of Urban E Regional Research, 27(4), 867-880.

https://doi.org/10.1111/j..2003.00488.x 
Ducatel, K., \& Blomley, N. (1990). Rethinking retail capital. International Journal of Urban \& Regional Research, 14(2), 207. https://doi.org/10.1111/j.14682427.1990.tb00669.x

Durkheim, E. (2002). Intihar. İstanbul: Cem Yayınevi.

EBSCO. (2019, Ocak 28). International Journal of Urban and Regional Research [Database]. Geliş tarihi gönderen Sociology Source Ultimate website:

https://www.ebsco.com/products/research-databases/sociology-sourceultimate

Feagin, J. R. (1987). Urban political economy: the new paradigm matures. JSTOR.

Fernández Kelly, M. P. (1994). Towanda's triumph: Social and cultural capital in the transition to adulthood in the urban ghetto. International Journal of Urban $\mathcal{E}$ Regional Research, 18(1), 88-111. https://doi.org/10.1111/j.14682427.1994.tb00252.x

Goonewardena, K. (2005). The urban sensorium: Space, ideology and the aestheticization of politics. Antipode Antipode, 37(1), 46-71.

Gottdiener, M., \& Feagin, J. (1988). The paradigm shifts in urban sociology. Urban Affairs Quarterly, 24(2), 163-187.

Grootaert, C., Narayan, D., Jones, V. N., \& Woolcock, M. (2004). Measuring social capital: An integrated questionnaire. The World Bank.

Grootaert, C., \& Van Bastelar, T. (2002). Understanding and measuring social capital: A multi-disciplinary tool for practitioners. The World Bank.

Gülhan, S. T. (2013). Özgürlüğün coğrafyası: Mekânsallığın triyalektik praksisi ve bütünsellik arayışına dair bir tahlil/geographies of liberation: Trialectics of spatial praxis and some ideas on the search for a totality. Mülkiye Dergisi, 37(1), 31-70.

Harvey, D. (1982). The limits to capital. Oxford: Blackwell.

Hawley, A. H. (1944). Ecology and human ecology. Social Forces, 22(4), 398-405. https://doi.org/10.2307/2571805

Holton, B. (1988). First International conference on the sociology of consumption, University of Oslo, January 1988 (Sy 03091317; s. 636). https://doi.org/10.1111/j.14682427.1988.tb00101.x

Kaika, M., \& Swyngedouw, E. (2000). Fetishizing the Modern City: The Phantasmagoria of Urban Technological Networks. International Journal of Urban $\mathcal{E}$ Regional Research, 24(1), 120-138.

Lefebvre, H. (1969). Les paradoxes d'Althusser. L'Homme et la société, 13(1), 3-37. https://doi.org/10.3406/homso.1969.1227

Lefebvre, H. (1991). The production of space. Oxford, OX, UK; Cambridge, Mass., USA: Blackwell.

Lévi-Strauss, C. (1955). Tristes tropiques. içinde Terre Humaine/Poche. Paris: Plon.

Lewis, O. (2011). The Children of Sanchez: Autobiography of a Mexican Family. Knopf Doubleday Publishing Group. 
Lojkine, J. (1976). Contribution to a Marxist Theory of Capitalist Urbanization. Içinde Urban Sociology: Critical Essays. London: Tavistock.

Martin, G. P. (2005). Narratives great and small: Neighbourhood change, Place and Identity in Notting Hill. International Journal of Urban \& Regional Research, 29(1), 67-88. https://doi.org/10.1111/j.1468-2427.2005.00570.x

Marx, K. (1993). Capital: Volume III: A Critique of Political Economy. Penguin Books.

Mayer, M. (2003). The onward sweep of social capital: Causes and consequences for understanding cities, communities and urban movements. International Journal of Urban E Regional Research, 27(1), 110-132. https://doi.org/10.1111/14682427.00435

Merrifield, A. (2002). Metromarxism; a Marxist tale of the city. New York: Routledge.

Milicevic, A. S. (2001). Radical intellectuals: What happened to the new urban sociology? International Journal of Urban and Regional Research, 25(4), 759-783.

Mormont, M. (1983). The emergence of rural struggles and their ideological effects. International Journal of Urban \& Regional Research, 7(4), 559. https://doi.org/10.1111/j.1468-2427.1983.tb00406.x

Mullins, P. (1991). Tourism urbanization. International Journal of Urban E Regional Research, 15(3), 326. https://doi.org/10.1111/j.1468-2427.1991.tb00642.x

Norclilffe, G. (1993). The regulation of Gerland: from mass production to flexible production in tony garnier's "cité industrielle". International Journal of Urban $\mathcal{E}$ Regional Research, 17(2), 195. https://doi.org/10.1111/j.1468-2427.1993.tb00476.x

Pahl, R. E. (1969). Urban social theory and research. Environment and Planning, 1(2), 143-153.

Pahl, R. E. (1989). Is the emperor naked? Some questions on the adequacy of sociological theory in urban and regional research. International Journal of Urban $\mathcal{E}$ Regional Research, 13(4), 709. https://doi.org/10.1111/j.1468-2427.1989.tb00143.x

Pahl, Ray E. (1977). Stratification, the relation between states and urban and regional development. International Journal of Urban and Regional Research, 1(2), 7.

Park, R. E. (2015). Topluluğun örgütlenmesi ve çocuk suçları. içinde Şehir: kent ortamındaki insan davranışlarının araştırılması üzerine öneriler. Ankara: Heretik.

Park, R. E., \& Burgess, E. W. (2015). Şehir: Kent ortamındaki insan davranışlarının araştırilması üzerine öneriler. Ankara: Heretik.

Parsons, T. (1968). The structure of social action: a study in social theory with special reference to a group of recent European writers. New York: Free press.

Pickvance, C.G. (1976). Urban sociology: critical essays. London: Tavistock Publications.

Pickvance, C.G. (1978). Marxist approaches to the study of urban politics: Divergences among some recent French studies. International Journal of Urban and Regional Research, 2(1), 219-255.

Podmore, J. (1998). (Re)reading the "loft living" habitus in Montréal's inner city. International Journal of Urban \& Regional Research, 22(2), 283. 
Portes, A., Castells, M., \& Benton, L. A. (1989). The Informal economy: studies in advanced and less developed countries. Baltimore, Md.: Johns Hopkins University Press.

Preteceille, E. (1981). Left-wing local governments and services policy in France. International Journal of Urban E Regional Research, 5(3), 411-425.

Putnam, R. D. (1995). Bowling alone: America's declining social capital. Journal of democracy, 6, 65-65.

Ranciére, J. (2009). Filozof ve yoksulları, çev. Aziz Ufuk Kılıç. İstanbul: Metis.

Ranciére, J. (2014). Cahil Hoca. İstanbul: Metis.

Savage, M. (2012). The lost urban sociology of Pierre Bourdieu. içinde The New Blackwell Companion to the City (ss. 511-520). https://doi.org/10.1002/9781444395105.ch45

Sik, E., \& Wallace, C. (1999). The development of open-air markets in east-central Europe. International Journal of Urban \& Regional Research, 23(4), 697-716.

Slater, T. (2006). The eviction of critical perspectives from gentrification research. International Journal of Urban \& Regional Research, 30(4), 737-757. https://doi.org/10.1111/j.1468-2427.2006.00689.x

Slater, T. (2008). 'A literal necessity to be re-placed': A rejoinder to the gentrification debate. International Journal of Urban E Regional Research, 32(1), 212-223. https://doi.org/10.1111/j.1468-2427.2008.00781.x

Small, A. W. (1895). The era of sociology. American Journal of Sociology, 1(1), 1-15.

Smart, J., \& Smart, A. (1991). Personal relations and divergent economies: A case study of Hong Kong investment in South China. International Journal of Urban \& Regional Research, 15(2), 216-233. https://doi.org/10.1111/j.14682427.1991.tb00631.x

Soja, E. (1980). The Socio-Spatial Dialectic. Annals of the Association of American Geographers, 70(2), 207-225.

Swedberg, R. (2011). The economic sociologies of Pierre Bourdieu. Cultural sociology, $5(1), 67-82$.

Swyngedouw, E. (2002). The strange respectability of the situationist city in the society of the spectacle. International Journal of Urban and Regional Research, 26(1), 153-165. https://doi.org/doi:10.1111/1468-2427.00369

Thompson, E. P. (1995). Poverty of Theory. London: Merlin.

Thuen, T. (1999). The significance of borders in the East European transition. International Journal of Urban E Regional Research, 23(4), 738-750.

Topalov, C. (1989). A history of urban research: the French experience since 1965. International Journal of Urban \& Regional Research, 13(4), 625-651. https://doi.org/10.1111/j.1468-2427.1989.tb00139.x

Wacquant, L. (2008). Relocating gentrification: The working class, science and the state in recent urban research. International Journal of Urban $\mathcal{E}$ Regional Research, 32(1), 198-205. https://doi.org/10.1111/j.1468-2427.2008.00774.x 
Wacquant, L. (2018). Bourdieu comes to town: Pertinence, principles, applications. International Journal of Urban \& Regional Research, 42(1), 90-105. https://doi.org/10.1111/1468-2427.12535

Wacquant, L. (1989). Towards a reflexive sociology a workshop with Pierre Bourdieu. Sociological Theory, 7(1), 26-63. https://doi.org/10.2307/202061

Wacquant, L. (1993). Urban outcasts: Stigma and division in the black American ghetto and the French urban periphery. International Journal of Urban $\mathcal{E} R e-$ gional Research, 17(3), 366-383. https://doi.org/10.1111/j.14682427.1993.tb00227.x

Wallace, C., Shmulyar, O., \& Bedzir, V. (1999). Investing in social capital: The case of small-scale, cross-border traders in post-communist central Europe. International Journal of Urban E Regional Research, 23(4), 751.

Warde, A. (1990). Production, consumption and social change: reservations regarding Peter Saunders' sociology of consumption. International Journal of Urban $\mathcal{E}$ Regional Research, 14(2), 228. https://doi.org/10.1111/j.1468-2427.1990.tb00670.x

Watt, P. (2006). Respectability, roughness and 'race': Neighbourhood place images and the making of working-class social distinctions in London. International Journal of Urban E Regional Research, 30(4), 776-797. https://doi.org/10.1111/j.1468-2427.2006.00688.x

Watt, P. (2008). The only class in town? Gentrification and the middle-class colonization of the city and the urban imagination. International Journal of Urban $\mathcal{E} R e-$ gional Research, 32(1), 206-211. https://doi.org/10.1111/j.1468-2427.2008.00769.x

Weber, M. (1992). The protestant ethic and the spirit of capitalism (T. Parsons, Çev.). London and New York: Routledge.

White, H. V. (1973). Metahistory: the historical imagination in nineteenth-century Europe. Baltimore: Johns Hopkins University Press.

White, H. V. (1978). Tropics of discourse essays in cultural criticism.

Wirth, L. (1938). Urbanism as a way of life. American Journal of Sociology, 44(1), 1-24. Woolcock, M., \& Narayan, D. (2000). Social capital: Implications for development theory, research, and policy. The world bank research observer, 15(2), 225-249. Zukin, S. (1980). A Decade of the new urban sociology. Theory and Society, 9(4), 575-601.

Sinan Tankut Gülhan 2014 yılında doktorasını Binghamton Üniversitesi (New York Eyalet Üniversitesi) Sosyoloji Bölümü'nden aldı. ODTÜ Sosyoloji Bölümü'nde lisans eğitimini 2003 yılında tamamladı. 2015 yılından beri Gaziantep Üniversitesi'nde öğretim üyesi olarak çalışmakta, aynı zamanda 2016 yılından bu yana Kent Çalışmaları lisansüstü programının koordinatörlüğünü sürdürmektedir. İlgi alanlarının arasında kentleşme ve şehircilik kuramları, Türkiye'de kentleşme, kentsel tarih, kent sosyolojisi ve mimarlık ve şehir planlamada eleştirel kuramlar yer almaktadır.

Sinan Tankut Gülhan is an assistant professor of sociology at Gaziantep University where he has been a faculty member since 2015 . He also chairs the 
graduate program in urban studies since 2016. He completed his Ph.D. in sociology at SUNY at Binghamton in 2014 and he got his undergraduate degree from METU in Ankara. His current research interests include urban theory, urbanization in Turkey, urban history, sociology of urbanization, and critical perspectives in architectural history and urban planning.

E-mail: sinantgulhan@outlook.com 